\title{
Mulka's Cave Aboriginal rock art site: its context and content
}

\author{
R. G. Gunn \\ 329 Mt Dryden Road, \\ Lake Lonsdale, Victoria 3380, Australia \\ email: gunnb@netconnect.com.au
}

\begin{abstract}
The Mulka's Cave Aboriginal site, within "The Humps" Nature Reserve near Hyden, Western Australia, was recorded in detail prior to an overall tourist-orientated development of the Reserve. The site features 452 motifs, an extremely high number for the region where most sites have fewer than 30 motifs. The artwork is dominated by 275 handstencils, with 40 sprayed areas, 23 handprints, 23 paintings, 3 drawings and a single object stencil produced with a wide range of colours. The high diversity of art attributes is unusual in a region where the rock art is dominated by red handstencils. The site appears to have been of considerable importance to the Noongar people in the past and remains significant to them today. Its significance to the broader Western Australian community is evidenced by the high number of tourists it currently receives.
\end{abstract}

\section{INTRODUCTION}

The Mulka's Cave Aboriginal site is a decorated rock shelter with an occupation deposit within "The Humps" Nature Reserve near Hyden, Western Australia. The site's management is to be upgraded as part of an overall tourist-orientated development of the Reserve. In line with this upgrade, the site's rock art has been recorded in detail for research, interpretation and conservation needs. The name "Mulka's Cave" derives from the associated Aboriginal myth (see below). The site is currently promoted to the general public and is estimated to receive around 80,000 visitors per year, a very high level of visitation for an Australian rock art site (excluding the exceptionally popular tourist sites at Uluru and Kakadu; Gale and Jacobs 1987). The recording was undertaken as part of the Wheatbelt Heritage Management Strategy of the Department of Indigenous Affairs. The strategy aims to develop a procedure of consultation with local Noongar people with respect to the management of Aboriginal sites within the Noongar Native Title area.

\section{THE SITE AND ITS CONTEXT}

Mulka's Cave is $18 \mathrm{~km}$ north-east of Hyden (Figure 1) and $300 \mathrm{~km}$ inland from Perth. It lies 15 $\mathrm{km}$ north of Wave Rock, the region's, and one of the nation's, premier tourist attractions. While Mulka's Cave is a promoted tourist attraction, it is largely "riding on the back" of the very successful Wave Rock tourism development.

Mulka's Cave has formed beneath a large boulder at the base of an outcrop of Archaean granite now known as The Humps (Figures 1 and 2). The outcrop is some $2 \mathrm{~km} \times 1.5 \mathrm{~km}$ in area and rises to $80 \mathrm{~m}$ above the surrounding plain (Twidale and Bourne 2003). It is the highest of several granite inselbergs in the region that form notable landmarks in an otherwise flat landscape. These inselberg were important for the Aboriginal people as both navigational guides and water reserves (Bindon 1997). The rock consists of "variably textured, medium and coarse grained seriate granite and adamellite" (Geological Survey of Western Australia 2003). Small, deeply weathered areas of the outcrop on the eastern side form linear ridges and tors, and it is beneath one of these tors that Mulka's Cave has formed.

The mean annual rainfall for the region is $345 \mathrm{~mm}$ (Bureau of Meteorology web site for Hyden). Rainfall tends to be heavier in winter (June $52 \mathrm{~mm}$ ) and lightest in December (mean $14 \mathrm{~mm}$ ), but can occur throughout the year. The temperature extremes range from $48^{\circ} \mathrm{C}$ in summer to $5^{\circ} \mathrm{C}$ in winter. The interior of Mulka's Cave does not receive any direct sunlight and hence it is not subject to the extreme temperature changes that are a common factor in rock deterioration (Twidale 1980: 134). Run-off water flows through the cave making the interior floor damp and slippery for prolonged periods after rain. This run-off has doubtless also affected the integrity of the archaeological deposits at the main entrance. Water, both flowing through the shelter and percolating through the rock matrix, is probably the principal agent for the massive exfoliation occurring within the shelter that threatens the existing artwork (cf. Twidale 1980: 142; Thorn 2001). 


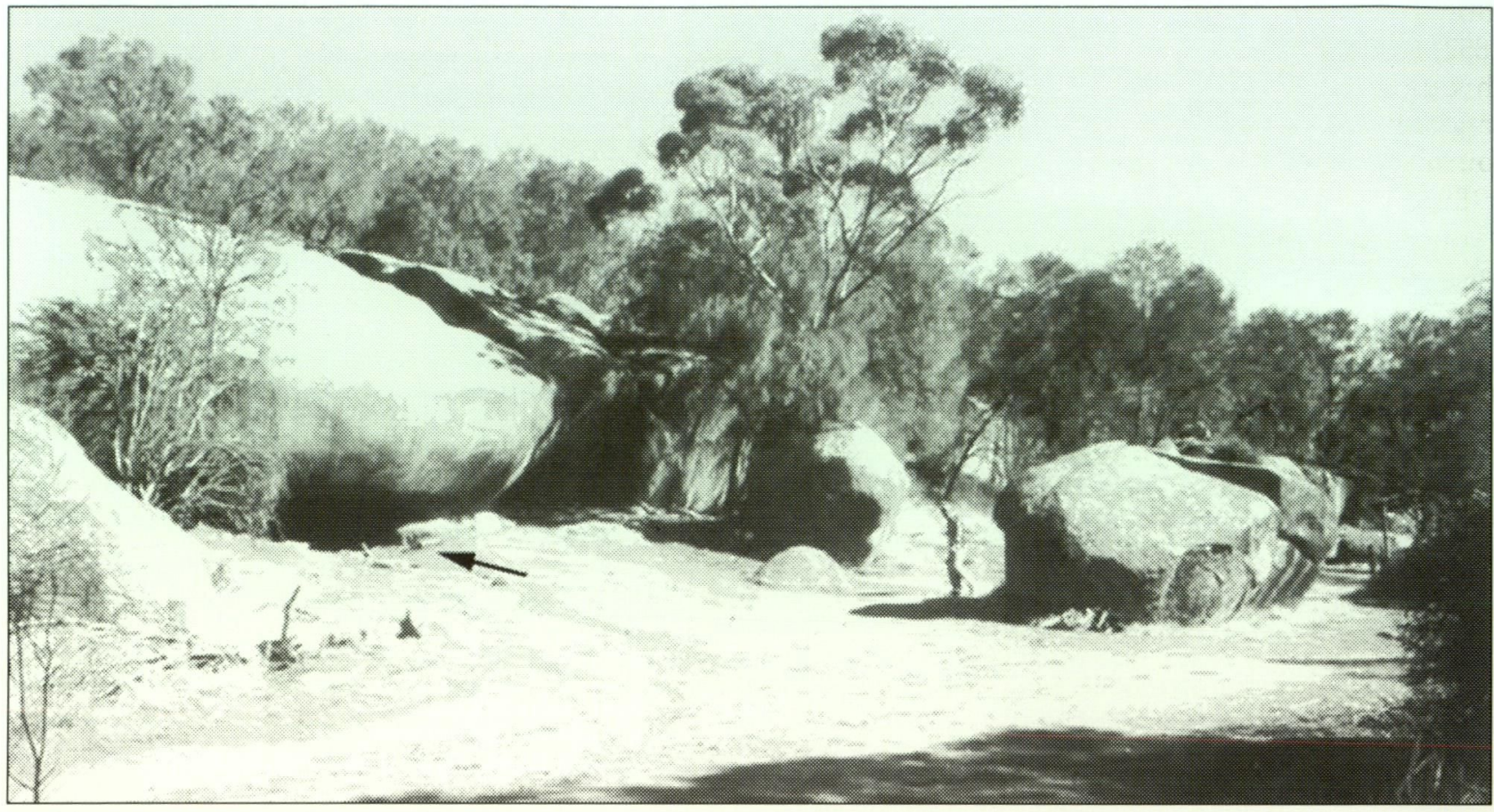

Figure 1 Mulka's Cave, The Humps, near Hyden. Main entrance arrowed.

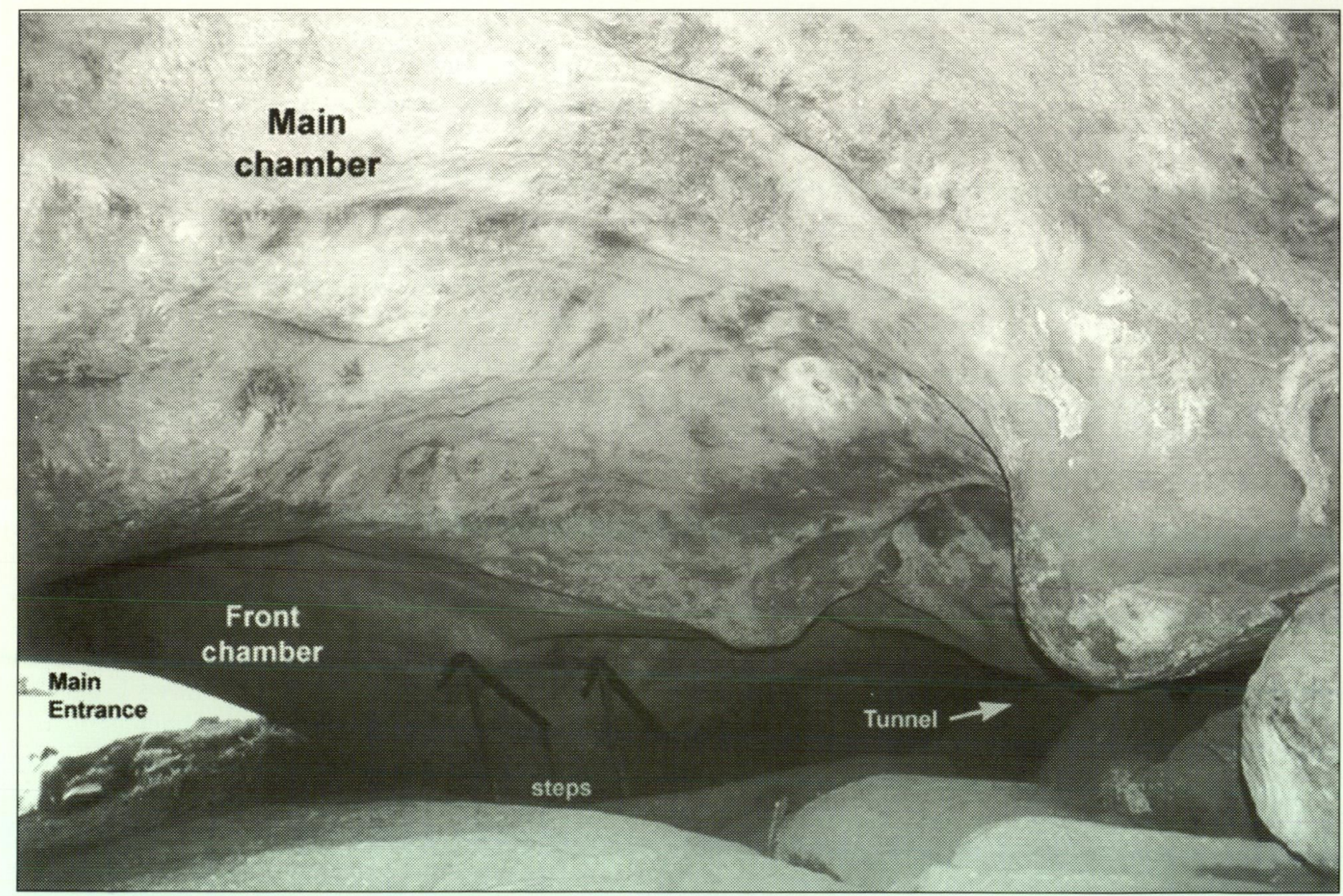

Figure 2 Interior of Mulka's Cave looking down to the main entrance from the main chamber.

The vegetation surrounding The Humps is essentially a mallee scrub with localised stands of salmon gums (Eucalyptus salmonophloia) (Bowdler et al. 1989), with pockets of relic vegetation on The Humps themselves (Twidale and Bourne 2003). Yams and wattle seeds are the only plant foods whose use by Indigenous hunter-gatherers is documented in the region 
(Bowdler et al. 1989). Early explorers (e.g., Roe 1852) found water and feed for their horses scarce throughout the region around Hyden, and sandalwood cutters relied upon the water they found in "granite rockholes" (Bowdler et al. 1989). As such they would have been of paramount importance to the Aborigines utilising the area (Bindon 1997).

The few early references to Aborigines around Hyden are scanty at best and have been interpreted as suggesting that the area was little visited because of its poor natural resources (Bowdler et al. 1989). However, the number and distribution of Aboriginal sites associated with gnammas across the region (Webb and Gunn 2004) suggests that the area was regularly visited following suitable rains.

Tindale (1974) placed the area around Hyden within the tribal area of the Njaki Njaki people who shared "overall cultural similarities" with the people of south-west Western Australia (Bowdler et al. 1989). Consequently, they were part of the southwestern cultural group known as the Goreng (Tindale 1974) or, more usually, Nyungar or Noongar (Berndt 1980). The Njaki Njaki were also known by the names Kokor and Kikkar (Tindale 1974). Today the site is within the area of the SouthWest Aboriginal Land and Sea Council (SWALSC) which represent the various Noongar groups of the South-West.

\section{Methods}

The Western Australian Department of Indigenous Affairs (DIA) contracted the author to produce a detailed recording of the site. The Department undertook initial consultation for the project and received permission and approval from the local and regional Noongar representatives for it to proceed. DIA subsequently organised an onsite meeting between the consultant and the local Noongar representatives when the recording aims and methods were fully explained. The Department also gave their permission for the publication of this paper.

A plan of the site was prepared using handheld GPS, with finer detail mapped by tape and compass. Arbitrary key points were placed on the art panels and mapped onto the plan. These were later used to integrate the photographic record into a photomosaic.

The shelter interior, which is poorly lit on even the brightest days, was illuminated using generatorpowered arc lights. The artwork was recorded by freehand sketching and photography, following published procedures (Gunn 1995a, 1995b) and a photomosaic subsequently prepared from which detailed drawings were made. Using the freehand sketches and the photographs, each image and area of pigment was allocated a discrete motif number.
Following Maynard $(1977,1979)$, a list detailing the attributes of technique, colour, form, type, condition and size for each motif was then compiled (Gunn 2004). Colour was generalised to orange-red, purple-red, brown-red, orange, yellow, cream and white. For hand stencils and prints, the knuckle size was measured on-site as an indicator of the size/age of the hand's owner. The maximum length of other distinct motifs was measured to the nearest half centimetre.

\section{The Mulka Dreaming}

Two versions of the story of Mulka have been published. The earliest is very brief:

The outcast Mulka, driven from the tribe because it was feared that his crossed eyes would bring a curse to those he looked upon, took refuge in the cave at the Humps (Meeking 1979).

The second comes from a brochure of the Department of Aboriginal Sites (DAS 1989):

Mulka was the illegitimate son of a woman who fell in love with a man to whom marriage was forbidden. As a result, Mulka was born with crossed eyes. Even though he grew up to be an outstandingly strong man of colossal height, his crossed eyes prevented him from aiming a spear accurately and becoming a successful hunter. Out of frustration, Mulka turned to catching and eating human children, and he became the terror of the district. He lived in Mulka's Cave where the impressions of his hands can still be seen much higher than those of an ordinary man. His mother became increasingly concerned with Mulka and when she scolded him for his anti-social behaviour, he turned on his own mother and killed her. This disgraced him even more and he fled the cave, heading south. Aboriginal people were outraged by Mulka's behaviour and set out to track down the man who had flouted all the rules. They finally caught him near Dumbleyung, $156 \mathrm{~km}$ south-west of Hyden, where they speared him. Because he did not deserve a proper ritual burial, they left his body for the ants; a grim warning to those who break the law.

Bowdler et al. (1989) consider this myth to be atypical of Aboriginal myths and consequently they dispute its origin. The author, however, has recorded similar myths in Central and Northern Australia, and considers this to be quite typical of local (non-travelling) myths, although even the longer version given here is likely to be a very much abridged rendition of a longer and more complex story. A myth with close similarities to the Mulka myth was also recorded by Meggitt (1962: 261-262) from the Warlpiri of Central Australia. [The Warlpiri are a Western Desert language group who share cultural links with the people to the east of the Noongar (see Gould 1969a; O'Connor et al. 1998, for maps)] 


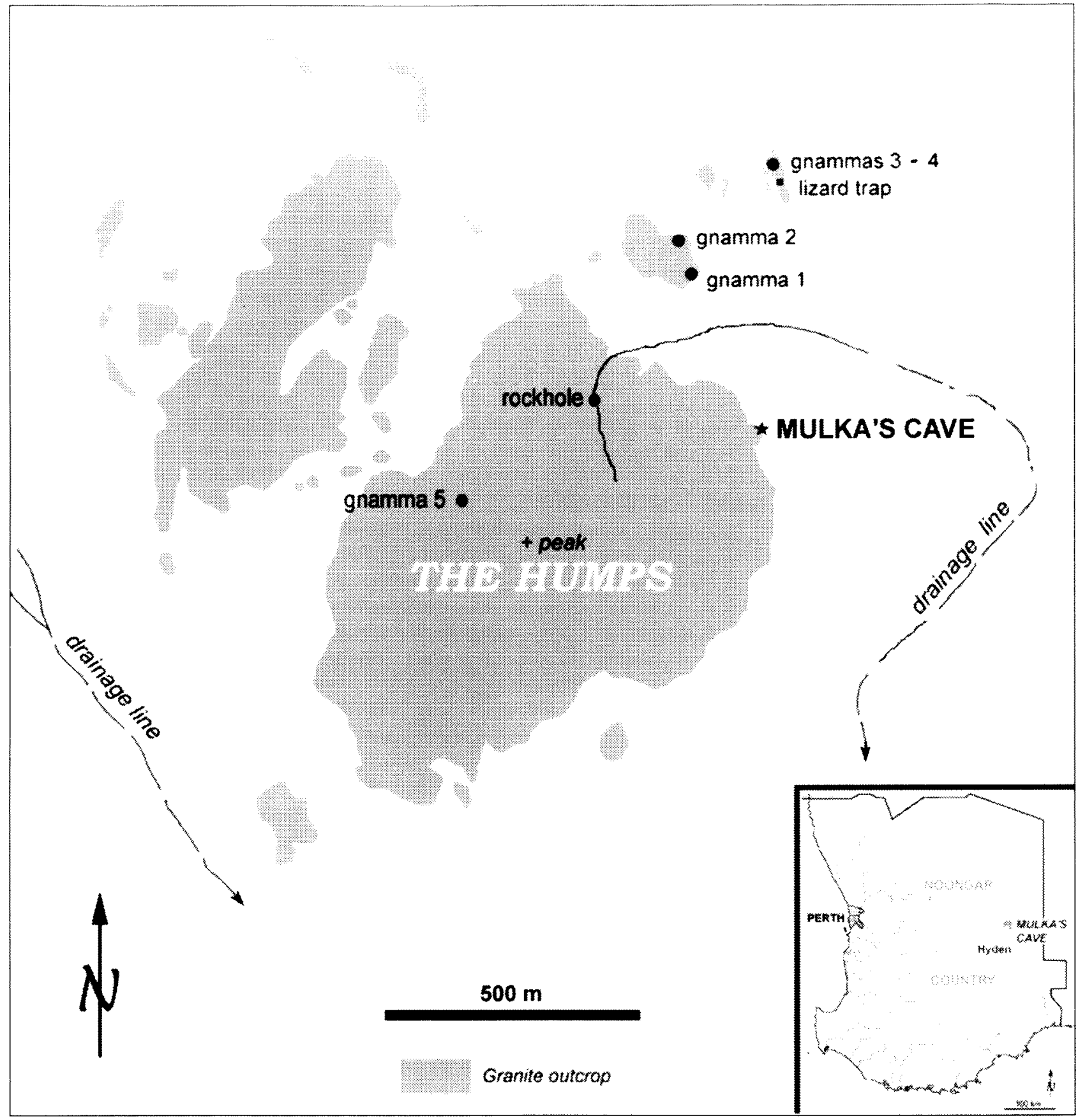

Figure 3 The Humps Reserve showing the location of the features of interest.

\section{Mulka's Cave}

Mulka's Cave is the only known rock art site within The Humps Reserve. In common with most Aboriginal rock art sites, Mulka's Cave is part of a larger site complex encompassing a range of other site types (cf. Gunn 1997). Here the associated sites consist of an adjacent open artefact scatter, a "lizard trap", five gnammas and a rockhole.

The Cave site lies at the base of the eastern slopes of the steep sided outcrop that forms The Humps hill (Figures 1,3). The lizard trap, rockhole and four of the gnammas occur on flat granite pavements $300 \mathrm{~m}$ to the north of the cave. The fifth gnamma lies on the northern mid-slope of the hill. This distribution of sites suggests that the principle area of Aboriginal interest was to the eastern side of the Reserve. While no further art sites or water reserves have been located on The Humps, no survey for stone artefacts has been undertaken to the west of the hill.

The first published account of the site was by $R$. B. Day (1951; quoted at length in Serventy 1952). Day mentioned that the site contained "hundreds of hand-marks done in red ochre... and the remnants of a large native drawing" but he did not provide any illustrations. Davidson had previously 
recorded the site in 1938-1939 but he did not publish his findings until the following year (Davidson 1952: 113). He identified seven paintings, 92 stencilled hands, and 37 printed or drawn hands.
These are in red, white or yellow pigments Davidson's study is the most detailed to date and is referred to further below. Serventy (1952), WolfeOkongwu (1978) and Flood (1990) also briefly
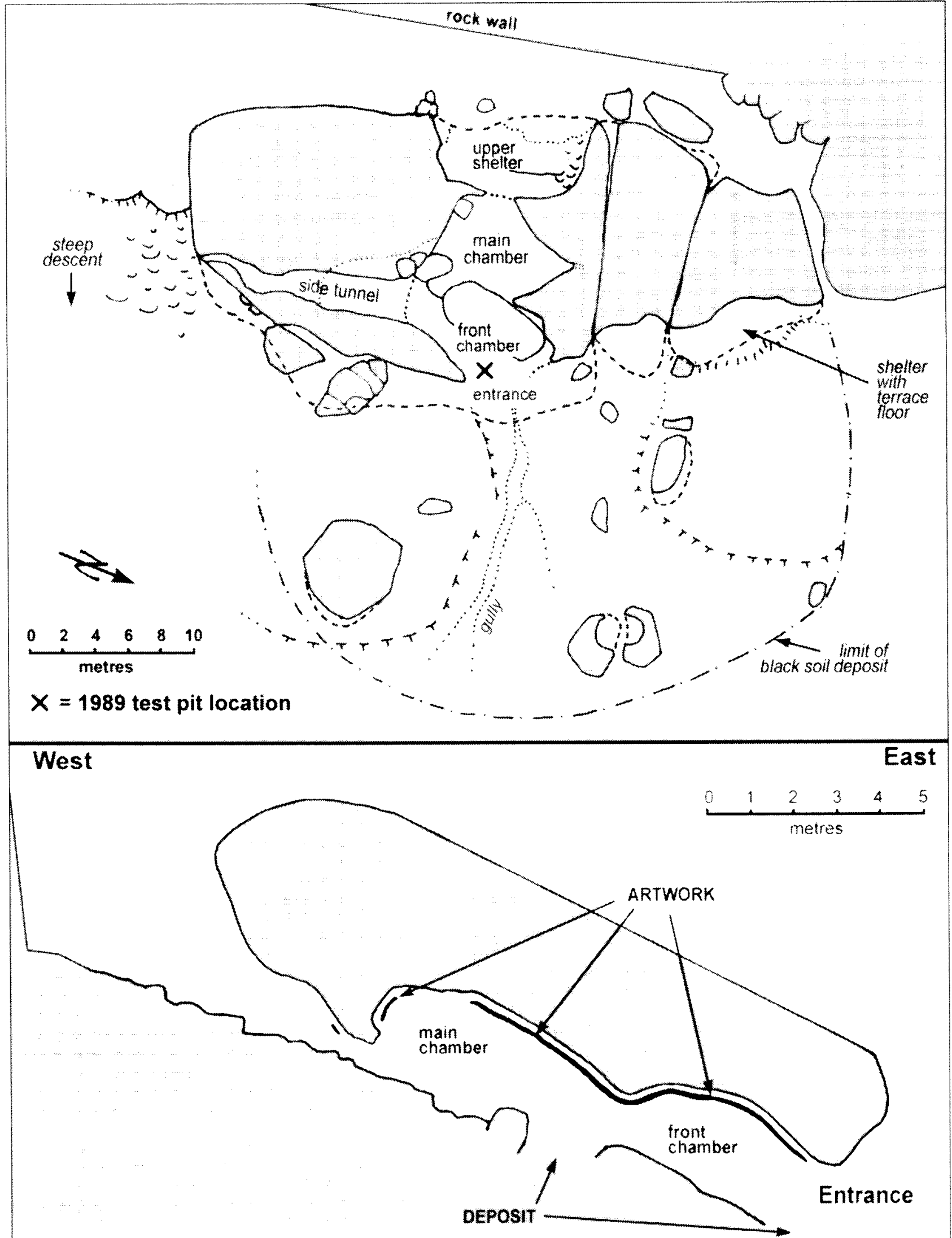

Figure 4 Mulka's Cave plan and section. 
discuss the site but incorporate few new details into their descriptions. Internal reports of the then Department of Aboriginal Sites (DAS; now DIA) offer further descriptions of the site including note of "a recent-looking painting in orange (?ochre) which is probably not Aboriginal" that has not been mentioned by previous researchers. This large and imposing work of graffiti was almost certainly produced between 1952 and 1971 and is excluded from the following description. A number of rock art conservation and management studies have been undertaken at Mulka's Cave (Randolph 1973; Clarke 1976; Haydock and Rodda 1986; Gunn 2003a) but these need not be discussed here.

\section{The Shelter}

Mulka's Cave is a tafone cavern underneath a large granite tor. A tafone (pl. tafoni) is a hollow or

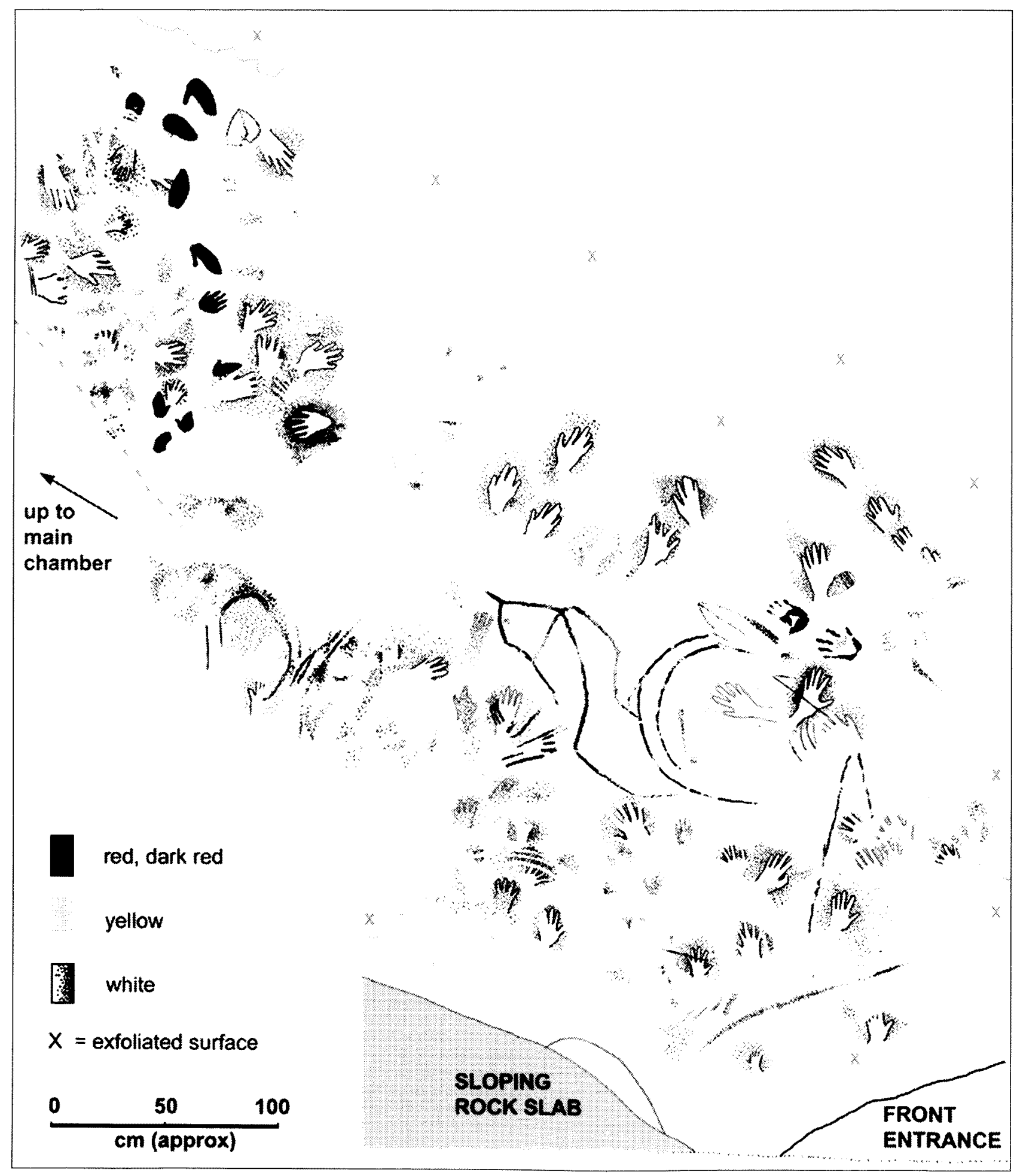

Figure 5 Front chamber artwork. 
cavern that develops on the underside of a boulder (Twidale and Bourne 1975: 481), while a tor as used here, is an Australian term for a "boulder of weathering" (Twidale 1980: 95-105). The tor here is $25 \mathrm{~m}$ long by $18 \mathrm{~m}$ wide and $5 \mathrm{~m}$ high and irregular in plan and section (Figure 4). The top of the tor slopes steeply $\left(20^{\circ}\right)$ downhill such that rainwater run-off is directed down over the shelter mouth, contributing to the erosion of the deposits in front of the shelter. The cave is a steeply inclined tunnel beneath the tor, with low entrances on both the downslope and upslope. The ground in front of the shelter slopes very gently down to the east, forming a level area that radiates for about $20 \mathrm{~m}$ out from the downslope (and main) entrance. Behind the shelter, The Humps hill rises rapidly in a series of vegetated rock benches. A number of large waterretaining pans are at the southern end of one of these benches, some $50 \mathrm{~m}$ south of, and $20 \mathrm{~m}$ above, the shelter.

Mulka's Cave is $15 \mathrm{~m}$ deep by $9 \mathrm{~m}$ wide, with a maximum height of $2.5 \mathrm{~m}$ above the floor. The interior is dark due to the low entrances and, while light penetrates through both entries, artificial light is required to see most of the artwork. For discussion and description, the cave is divided into five units on the basis of its interior morphology: main entrance, front chamber, main chamber, upper shelter and side tunnel (Figure 4).

The "front chamber" is immediately inside the main entrance (Figures 2, 4). It is $6 \mathrm{~m}$ wide and deep, with a domed ceiling up to $2 \mathrm{~m}$ high. Artwork covers most of the ceiling, with the exception of the actively eroding southern wall. The rear of the chamber is taken up with a large sloping block of granite. The chamber is divided from the main chamber by this block and a corresponding drop in the ceiling height. The floor consists of a flat deposit of grey sand in a narrow strip that runs diagonally back and into the side tunnel chamber. This was found to be rich in archaeological material (Bowdler et al. 1989; discussed below).

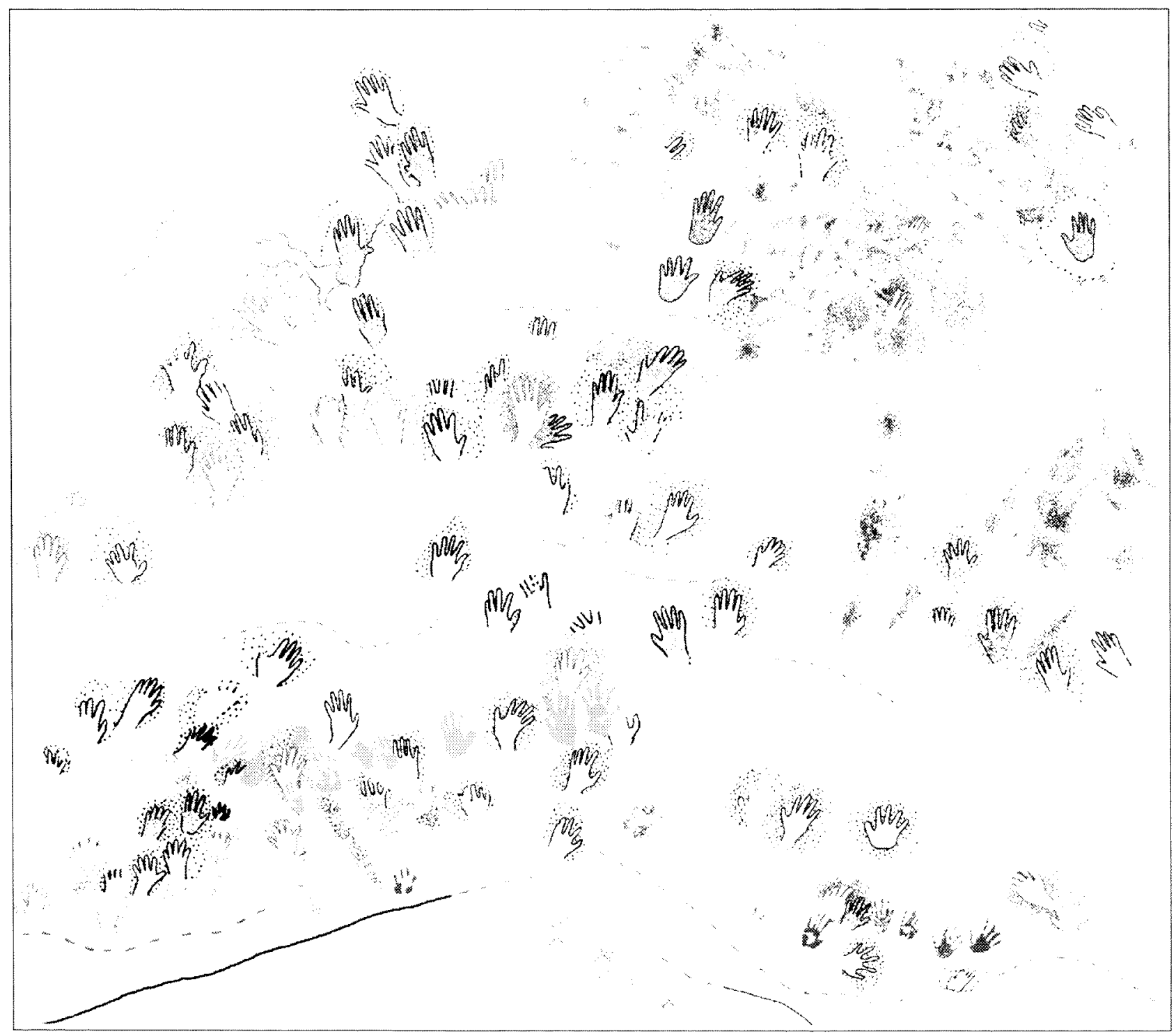

Figure 6 Main chamber artwork detail. 
The "main chamber" is $6 \mathrm{~m}$ wide by $9 \mathrm{~m}$ deep, with a domed and undulating ceiling that rises to a maximum height of $2.5 \mathrm{~m}$ above the floor. The floor slopes steeply $\left(\mathrm{c} .20^{\circ}\right)$ towards the entrance and at its lowest point is $1.5 \mathrm{~m}$ above the floor of the front chamber. Boulders cover most of the floor but there is a small area of flat soil at the lowest point. These boulders are convenient to sit on but there is little flat area suitable for sleeping. Towards the back entrance, the floor is covered by smaller, loose rocks (c. $0.5 \mathrm{~m}$ diameter). Artwork covers most areas of the ceiling but with a denser concentration on the downhill side (facing uphill and away from the entrance; figure 2). This area of ceiling is the most obvious to decorate for people sitting in the cave.

The "upper shelter" is on the uphill side of the tor. Although it is $10 \mathrm{~m}$ wide, $5 \mathrm{~m}$ deep and $2 \mathrm{~m}$ high, the floor is both steep and rock strewn, making it unsuitable for occupation. A small panel of artwork occurs directly above this entry.

The "side tunnel" is about $12 \mathrm{~m}$ long. Although $1.5 \mathrm{~m}$ wide and high at its mouth, it decreases rapidly in width such that despite its flat soil floor, only the first six meters is comfortable to sit in. There is no artwork within the tunnel, whose ceiling and walls are actively deteriorating.

\section{The Artwork}

A total of 452 motifs were recorded from three alcoves within the cave (Figures 5 and 6). [The full list of motifs and their attributes is given in Gunn (2004).] The front chamber has 131 motifs, the main chamber 318 , and the rear shelter three. The densest area is on the downhill face of the main chamber ceiling. The northern sidewall is most easily viewed without artificial lighting. The quantity of artwork on the eastern face suggests that the Aboriginal artists would have worked with artificial lighting.

The absence of motifs within the side tunnel and the south wall of the front chamber is probably attributable to moisture and consequent rock deterioration. The small number of motifs within the rear shelter most likely reflects its unsuitability for occupation as well as its water-washed wall surface, while the total lack of extant artwork on the outside wall at the main entrance can be attributed to its water-washed surface.

A lack of artwork on the dry wall of an adjacent shelter to the immediate north of the cave, however, is less readily explained. This small shelter has a flat floor with a light scatter of stone artefacts, indicating that it was used in the past, presumably by the same people who decorated Mulka's Cave.

\section{Motif types}

Eighteen distinct motif types were recorded in Mulka's Cave (Table 1). Visually and numerically the artwork is dominated by hands (69\%); these are primarily stencils but include a few handprints (Figures 5 and 6). Left hands outnumber right hands 108 to 72 (a ratio of 1.5:1). Similar ratios occur throughout Australia and are thought to reflect the proportion of left and right handed people in the population, as right-handed people tend to stencil their left hands and vice versa (Gunn in prep). While most of the hand stencils and prints are of the standard type with splayed fingers, a small number of the stencils are variants (cf. Walsh 1979), with the second (middle) and third (ring) fingers held together (Figure 7). Among the handprints, a

Table 1 Motif types by technique.

\begin{tabular}{|c|c|c|c|c|c|}
\hline Motif Type & Print & Spray & Paint & Draw & Total \\
\hline Unknown object & & 1 & & & 1 \\
\hline Spray area & & 37 & & & 37 \\
\hline Variant hand & 9 & 11 & & & 20 \\
\hline Right hand & 10 & 62 & & & 72 \\
\hline Unknown hand & 14 & 99 & & & 113 \\
\hline Left hand & 4 & 103 & 1 & & 108 \\
\hline Band & & 1 & 1 & & 2 \\
\hline Other apex element & & & 2 & 2 & 4 \\
\hline Arc set & & & 1 & 1 & 2 \\
\hline Bar set & & & 5 & & 5 \\
\hline Line single & & & 3 & & 3 \\
\hline Other element & & & 2 & & 2 \\
\hline Arc pair & & & 1 & & 1 \\
\hline V shape & & & 1 & & 1 \\
\hline Line pair & & & 1 & & 1 \\
\hline Simple design $\mathrm{k} 1 \mathrm{a}$ & & & 1 & & 1 \\
\hline Simple design $\mathrm{k} 1 \mathrm{~b}$ & & & 1 & & 1 \\
\hline Simple design $k 3$ & & & 1 & & 1 \\
\hline Total & 37 & 314 & 21 & 3 & 375 \\
\hline Fragments & & 75 & 2 & & 77 \\
\hline$\%$ & 8 & 86 & 5 & $<1$ & 100 \\
\hline
\end{tabular}




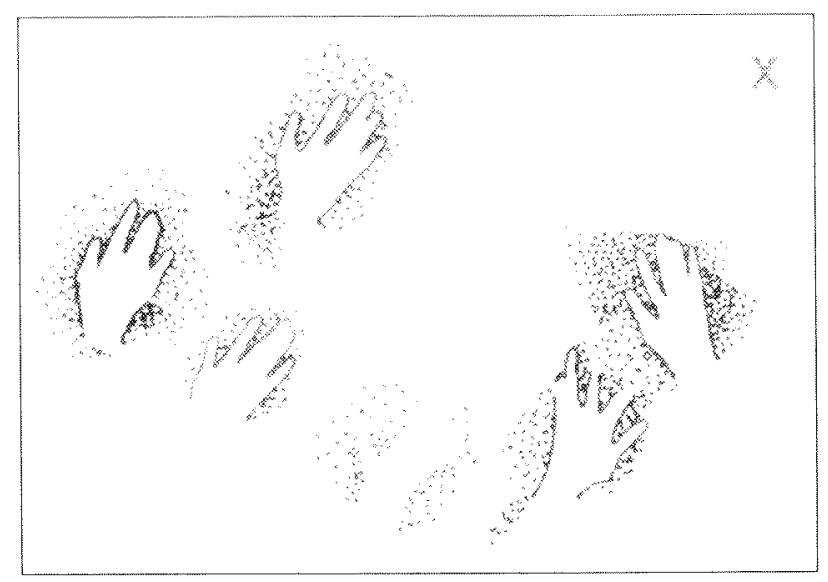

Figure 7 Group of red "variant" handstencils.

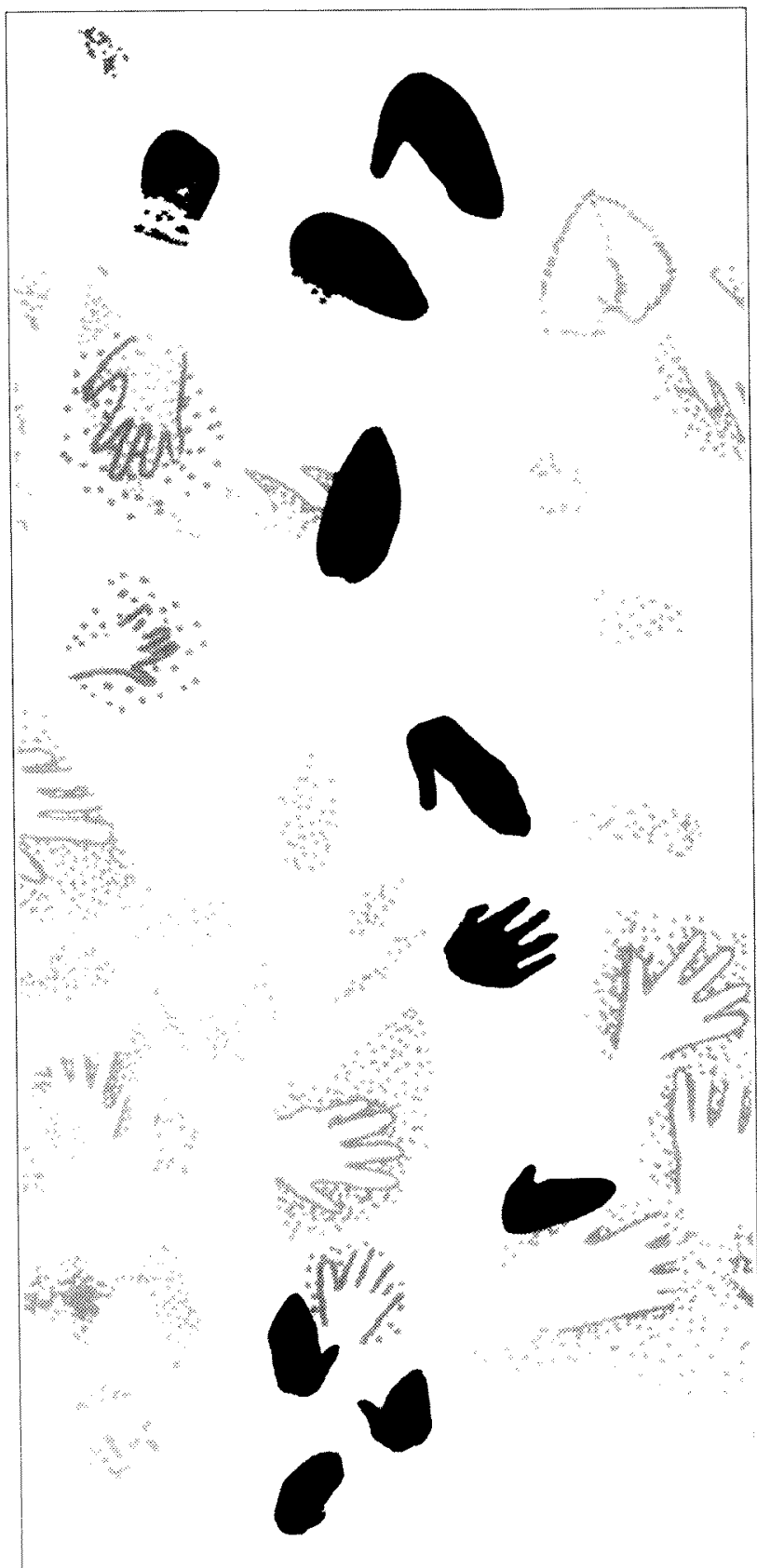

Figure 8 Group of red "variant" handprints, possibly imitating a trail of macropod tracks. few have all their fingers closed together but with the thumb splayed, giving the shape of a kangaroo or other macropod track (Figure 8; and see McDonald 1983), but whether this resemblance was intentional or fortuitous is unknown.

Solid areas of pigment sprayed onto the wall (in the manner of a stencil but without stencilled object) are a feature of the artwork. Several are unusually large, up to $40 \mathrm{~cm}$, and involve the use of a considerable amount of pigment. No ochre source is known in the immediate vicinity and hence it is assumed that the ochres used here would have to have been brought in from some distance away. Consequently the use of large quantities of ochre implies some particular value in the artwork produced even though no recognisable image is apparent. It is probable then that the importance was in the application of pigment to the wall rather than the production of any particular image. This would then fall into one of Ross's "associated rock art traditions" that include other non-image works such as abraded areas, scribble areas, etc. (Ross 2003: 89).

Two large, linear, simple designs in the front chamber are the most visually impressive motifs in the cave (Figure 9). Other motifs consist of small "geometric element" motifs: bars, lines and arcs, in either sets or other various combinations (Figure 10). This graphically simple repertoire is consistent with the pattern of rock art throughout much of southern Australia (Wolfe-Okongwu 1978; Gunn 1981, 1983, 2002).

Small numbers of large linear designs within a suite of numerous handstencils is now becoming apparent throughout south-west Western Australia (Hallam 1972; Gunn and Webb 2003). White all of the design motifs are similar in structure (linear), they are unique in their individual designs.

\section{Techniques}

Four art production techniques were recorded in Mulka's Cave (Table 2): spraying $(86 \%)$, printing $(8 \%)$, painting $(5 \%)$ and drawing $(<1 \%)$.

Table 2 Motif colour by technique.

\begin{tabular}{|c|c|c|c|c|c|c|}
\hline Colour & Paint & Spray & Print & Draw & Total & $\%$ \\
\hline \multicolumn{7}{|l|}{ Monochrome } \\
\hline Red (brown-red) & 6 & 2 & & & 8 & 2 \\
\hline Yellow & 1 & 18 & & & 19 & 4 \\
\hline Red (purple-red) & 8 & 199 & 18 & & 225 & 50 \\
\hline White & 3 & 106 & 2 & & 111 & 25 \\
\hline Red (orange-red) & 5 & 28 & 7 & 3 & 43 & 10 \\
\hline Orange & & 1 & 3 & & 4 & $<1$ \\
\hline Cream & & & 7 & & 7 & 2 \\
\hline \multicolumn{7}{|l|}{ Bichrome } \\
\hline White+red & & 32 & & & 32 & 7 \\
\hline Yellow+red & & 2 & & & 2 & $<1$ \\
\hline Whiteryellow & & 1 & & & 1 & $<1$ \\
\hline Total & 23 & 389 & 37 & 3 & 452 & \\
\hline
\end{tabular}




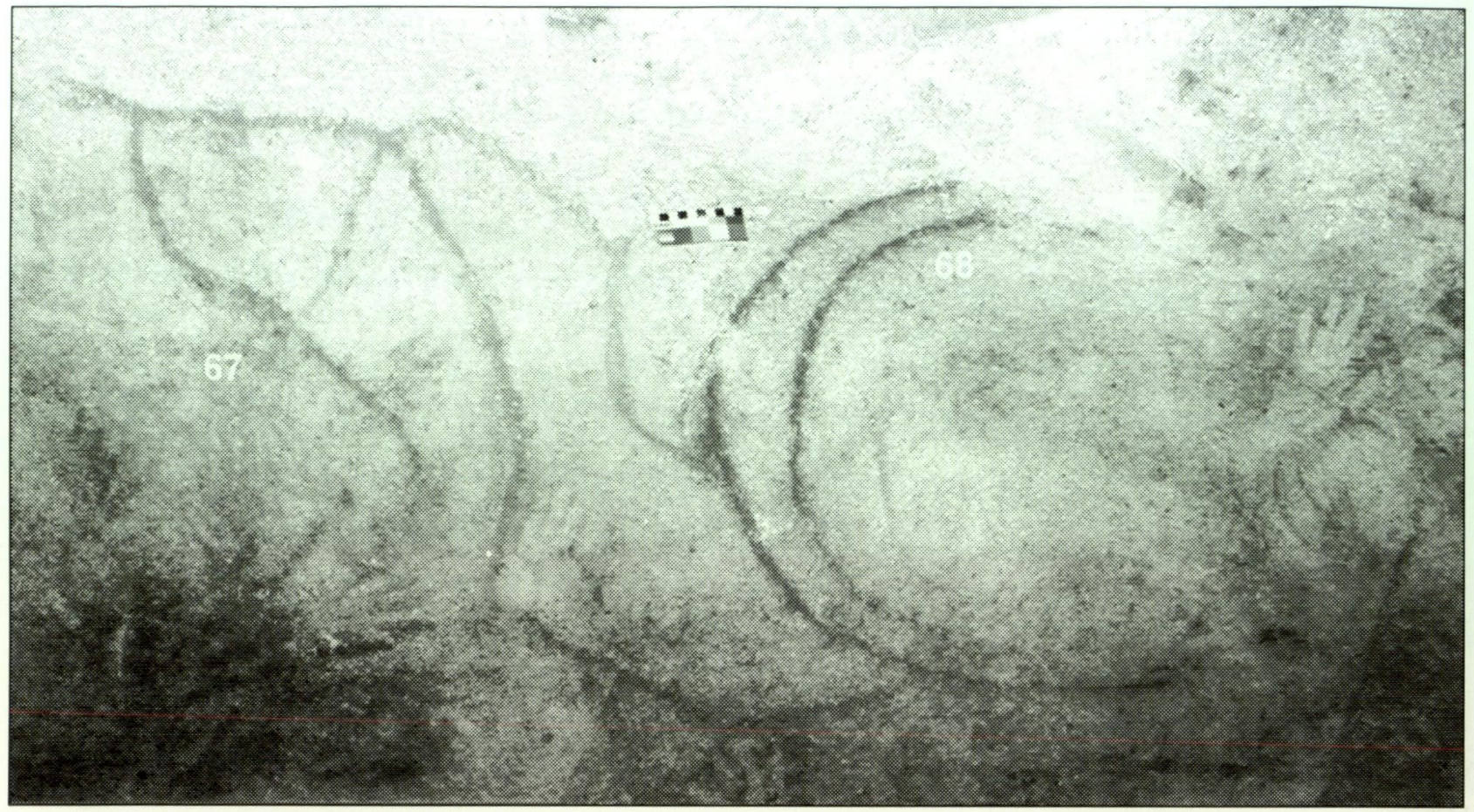

Figure 9 The major paintings in the front chamber of Mulka's Cave. Motif 68 is in purple-red and overlies motif 67 in an orange-red. Motif 67 is $1270 \mathrm{~mm}$ and motif 68 is $830 \mathrm{~mm}$. The colour scale is $10 \mathrm{~cm}$.

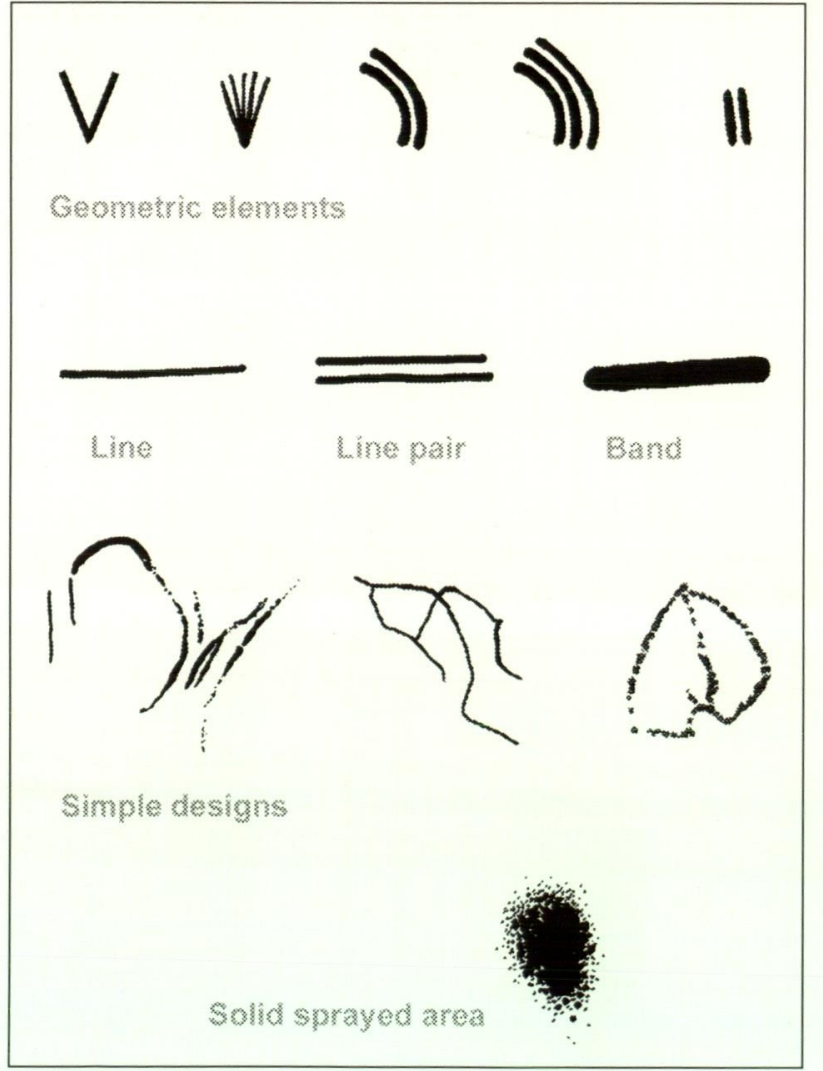

Figure 10 Freeform motif types.

Of the sprayed motifs, 38 are solid areas of sprayed pigment, while the others are sprayed over an object, most commonly a hand, that was then removed leaving a negative stencil image. Although most of the stencils were produced on an area of bare rock wall, 35 were produced by placing the hand on a pre-pigmented surface (Figure 11). Although artworks produced by this technique are known elsewhere in Australia in small numbers, the number of examples here make the technique a feature of the Mulka's Cave art. In some instances this appears to be incidental overlap, but in a number of cases the placement is central to the pigment area and therefore probably deliberate. While it is not possible to determine whether or not the original pigment was applied immediately before the stencilling (and hence as part of the stencilled motif), or whether a previously sprayed area was deliberately chosen, a number of examples suggest the former. In these cases, red pigment was used as the underlying colour and white as the stencilling colour. Due to some unusual character of the pigment or the wall surface itself, the white pigment has dropped off the wall taking with it the underlying red pigment. What remains is a positive red image, of the negative stencilled hand, within a field devoid of pigment. Superficially these resemble handprints, yet the character of the hand is distinctly in the form of a stencil. Other examples in the cave demonstrate the intermediary stages of this deterioration process and clearly show the white overlying the earlier red layer.

In contrast to stencils which produce a negative image, printing produces a positive image by imprinting a pigment-laden object, again usually a hand, directly onto the rock surface. Here only handprints occur, both standard splayed hands and 

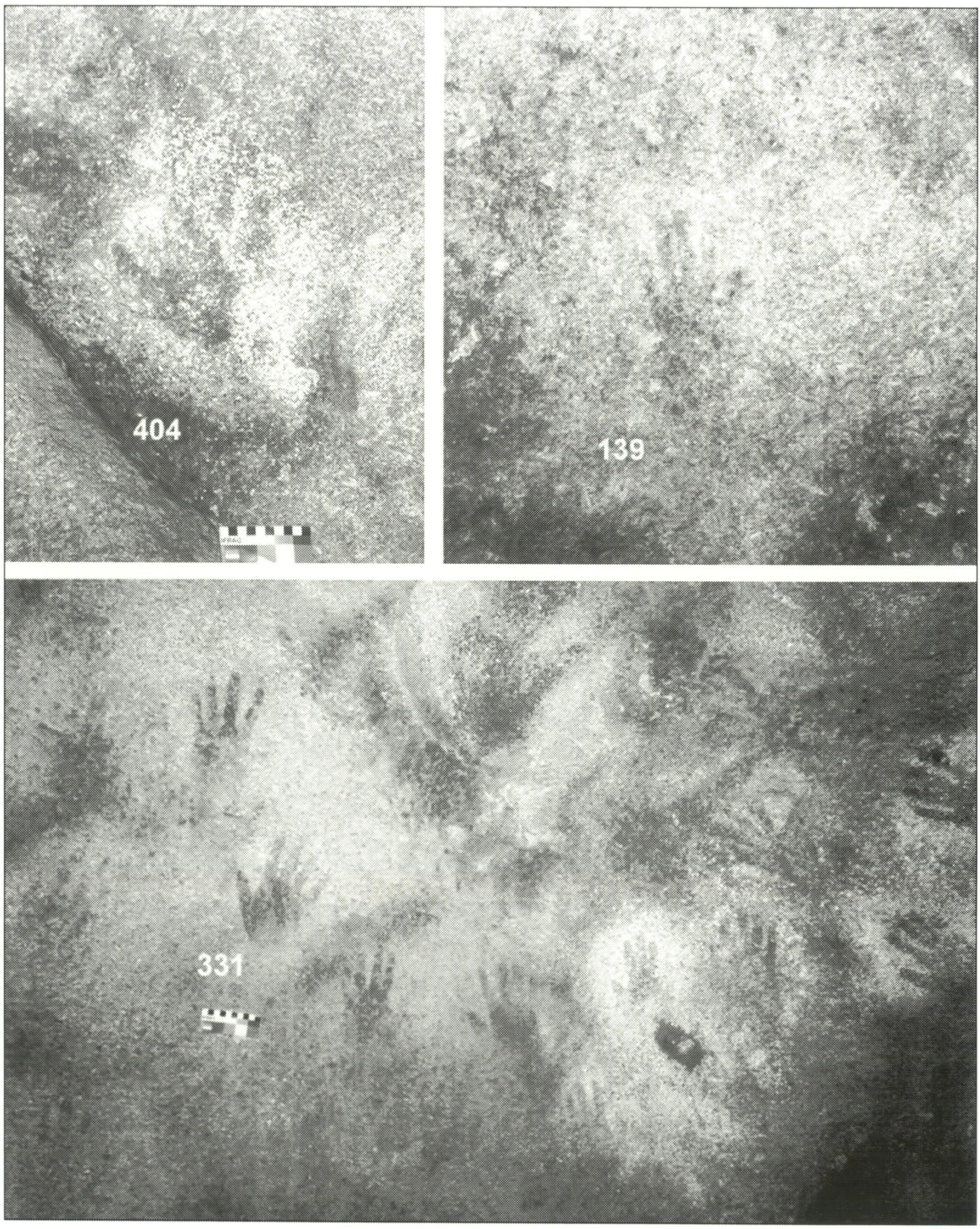

Figure 11 White handstencils over red pigment areas in Mulka's Cave. The white pigment and the underlying red have eroded away leaving a red positive hand on a bare rock surface. The motifs in the upper two photographs retain fragments of white pigment around the red hand. 
some "variant" hands with non-evenly splayed fingers (Figure 8).

The paintings, due to the lack of any brush striations, appear to have been executed with a daubed finger rather than any form of brush. The drawings were produced using a dry ochre nodule, in the manner of a crayon.

The motifs tend to form two groups (Table 1):

- Paintings and drawings : Geometric elements and simple designs

- Sprays and prints : : Hands, objects and spray areas

This is a common division in pictogrammic art (e.g., the "art" and "associated art traditions" divisions of Ross 2003) where "freeform" images (where the shape of the object is determined by the artist's mental image) are distinct from preform" images (where the shape of the image is derived from an actual object or by the technique itself)(see below).

\section{Colour}

Seven distinct colours were recorded (Table 2): purple-red $(50 \%)$, white $(25 \%)$, orange-red $(10 \%)$, and brown-red, yellow, cream, and orange in smaller numbers. The three reds appear to be distinctly different hues, but analysis may show them to be the same colour in various stages of preservation. Purple-red is the most common colour among the sprays, prints and paintings.

Three bichrome colour combinations were also recorded: white+red, white+yellow, and yellow+red. These are all handstencils produced over an underlying colour. Cream is restricted to printing. However, as the number of motifs involved in these two groups is small, the distinctions are not considered significant at this stage. On the other hand, the lack of yellow handprints and the very small number of white prints (two, cf 106 white stencils) appears culturally motivated, as the pigments were obviously readily available.

A matrix of colour and motif types shows that whereas hands and sprayed areas are made with a wide range of colours, geometric elements and designs use a limited range basically restricted to the three reds (Table 3). Contrary to Davidson (1952), who found that left and right hands occur in equal numbers with all colours, the author found that when all hands are included, left hands predominate over right in all colours in a ratio ranging from $1.5: 1$ to $2: 1$.

\section{Motif forms}

Six motif form types were identified (Table 4): handstencil $(73 \%)$, solid $(11 \%)$, handprint $(10 \%)$, linear $(6 \%)$, and single examples of an object stencil and an outlinetinfill painted motif. Motif form can be subdivided into preforms, where the form is dictated by the technique used, for example handstencils, and freeforms, where the form is independent of the technique, such as paintings. The preforms recorded here account for $93 \%$ of the motifs, and comprise hand and object stencils, handprints and sprayed areas. The freeform motifs are dominated by linear types, the most complex of which is a simple outline+infill design. Apart from the solid sprayed areas, and a single painted "hand" motif, there is a distinct separation of the motif types between freeforms and preforms (Table 4).

The single yellow object stencil is a narrow shaft about a metre long and $25 \mathrm{~mm}$ thick. Its simple

Table 3 Motif type by colour.

\begin{tabular}{|c|c|c|c|c|c|c|c|c|c|c|c|}
\hline Motif Type & $\mathrm{rb}$ & $\mathrm{rp}$ & ro & $w$ & $\mathrm{y}$ & $w+r$ & c & o & $y+r$ & $w+y$ & Total \\
\hline V shape & 1 & & & & & & & & & & 1 \\
\hline Line pair & 1 & & & & & & & & & & 1 \\
\hline Arc pair & & 1 & & & & & & & & & 1 \\
\hline Other element & 1 & 1 & & & & & & & & & 2 \\
\hline Line set & 2 & 1 & & & & & & & & & 3 \\
\hline Simple design $\mathrm{k} 1 \mathrm{~b}$ & & & 1 & & & & & & & & 1 \\
\hline Simple design $k 3$ & & & 1 & & & & & & & & 1 \\
\hline Arc set & & 1 & 1 & & & & & & & & 2 \\
\hline Band & & 1 & 1 & & & & & & & & 2 \\
\hline Other apex element & & 1 & 2 & & 1 & & & & & & 4 \\
\hline Bar set & 1 & & 2 & 2 & & & & & & & 5 \\
\hline Left hand & 1 & 35 & 4 & 45 & 6 & 14 & 2 & & 1 & & 108 \\
\hline Unknown hand & & 47 & 11 & 37 & 5 & 9 & 2 & 2 & & & 113 \\
\hline Right hand & & 24 & 8 & 22 & 3 & 8 & 3 & 2 & 1 & 1 & 72 \\
\hline Spray area & & 34 & 1 & & 2 & & & & & & 37 \\
\hline Variant hand & & 17 & 1 & 1 & & 1 & & & & & 20 \\
\hline Simple design $k 1 a$ & & & & 1 & & & & & & & 1 \\
\hline Unknown & & & & & 1 & & & & & & 1 \\
\hline Total & 7 & 163 & 33 & 108 & 18 & 32 & 7 & 4 & 2 & 1 & 375 \\
\hline Fragments & 1 & 62 & 10 & 3 & 1 & & & & & & 77 \\
\hline
\end{tabular}


Table 4 Motif types by form.

\begin{tabular}{|c|c|c|c|c|c|c|c|}
\hline Motif type & $\begin{array}{r}\text { Preforms } \\
\text { Object } \\
\text { stencil }\end{array}$ & $\begin{array}{l}\text { Hand } \\
\text { stencil }\end{array}$ & $\begin{array}{l}\text { Hand } \\
\text { print }\end{array}$ & $\begin{array}{l}\text { Freeforms } \\
\text { Linear }\end{array}$ & Solid & $\begin{array}{l}\text { Outline } \\
\text { +infill }\end{array}$ & Total \\
\hline & $b$ & $\mathrm{~h}$ & $t$ & 1 & s & oi & \\
\hline Unknown & 1 & & & & & & 1 \\
\hline Variant hand & & 11 & 9 & & & & 20 \\
\hline Right hand & & 62 & 10 & & & & 72 \\
\hline Unknown hand & & 99 & 14 & & & & 113 \\
\hline Left hand & & 103 & 4 & 1 & & & 108 \\
\hline$V$ shape & & & & 1 & & & 1 \\
\hline Other apex element & & & & 4 & & & 4 \\
\hline Arc set & & & & 2 & & & 2 \\
\hline Arc pair & & & & 1 & & & 1 \\
\hline Bar set & & & & 5 & & & 5 \\
\hline Fragments & & & & 2 & & & 2 \\
\hline Line single & & & & 3 & & & 3 \\
\hline Line pair & & & & 1 & & & 1 \\
\hline Simple design $\mathrm{k} 1 \mathrm{a}$ & & & & 1 & & & 1 \\
\hline Simple design $k 1 b$ & & & & 1 & & & 1 \\
\hline Other element & & & & 1 & 1 & & 2 \\
\hline Band & & & & & 2 & & 2 \\
\hline Spray area & & & & & 37 & & 37 \\
\hline Simple design $k 3$ & & & & & & 1 & 1 \\
\hline Total & 1 & 275 & 37 & 23 & 40 & 1 & 377 \\
\hline$\%$ & $<1$ & 73 & 10 & 6 & 11 & $<1$ & \\
\hline
\end{tabular}

Table 5 Knuckle size statistics for stencils and prints $(\mathrm{mm})$.

\begin{tabular}{lcc}
\hline & Stencils & Prints \\
\hline min & 50 & 70 \\
max & 90 & 90 \\
mean & 80 & 80 \\
median & 80 & 75 \\
sd & 7.0 & 7.0 \\
$n$ & 106 & 11 \\
\hline
\end{tabular}

shape offers few clues to its identification. It could be a spear, a piece of ceremonial paraphernalia, a thin digging stick, or simply a straight stick.

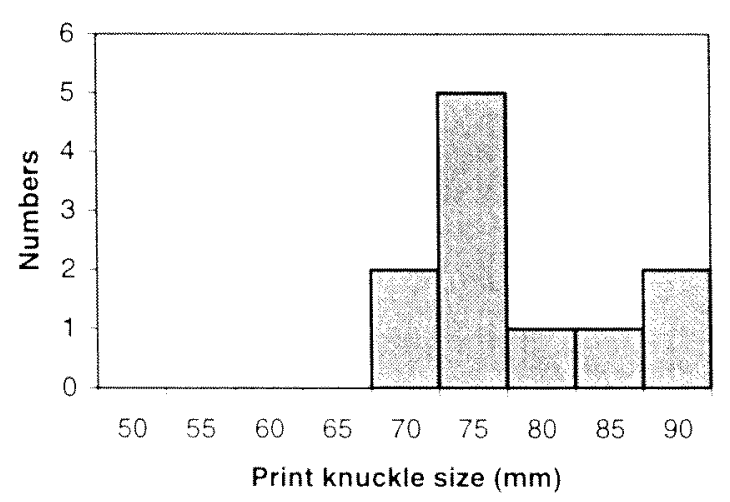

Figure 12 Hand stencil knuckle size frequencies $(n=106)$.

\section{Motif size}

The width at the knuckles of stencilled and printed hands was recorded as an indication of the stature and possible age of the hand's owner (Table 5, Figures 12 and 13). Hand size can therefore indicate the population range that decorated the site. The stencils range in size from $50 \mathrm{~mm}$ to 90 $\mathrm{mm}$ with a mean of $80 \mathrm{~mm}$. The prints range from $70 \mathrm{~mm}$ to $90 \mathrm{~mm}$, but also with a mean of $80 \mathrm{~mm}$. In general, the knuckle measurements of stencils are 5 $\mathrm{mm}$ larger than the knuckles of the hand stencilled, and printed knuckles $5 \mathrm{~mm}$ smaller. Hence, the two techniques represented in Mulka's Cave seem to represent the same population group. The presence of two very small hands (knuckle sizes $50 \mathrm{~mm}$ and $55 \mathrm{~mm}$ ) amongst the stencils suggests that infants

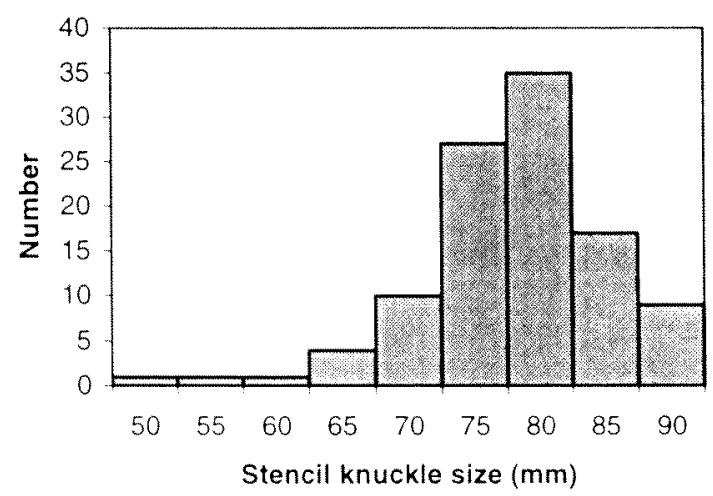

Figure 13 Hand print knuckle size frequencies $(n=11)$. 
Table 6 Technique and colour by knucklesire $(\mathrm{mm})$.

\begin{tabular}{|c|c|c|c|c|c|c|c|c|c|c|c|}
\hline Technique & Colour & 50 & 55 & 60 & 65 & 70 & 75 & 80 & 85 & 90 & (n) \\
\hline \multirow[t]{8}{*}{ Stencils } & Red-brown & & & 1 & & & & & & & 1 \\
\hline & Red-orange & & & & & & 1 & 2 & 1 & & 4 \\
\hline & Red-purple & 1 & 1 & & 1 & 4 & 13 & 14 & 9 & 1 & 44 \\
\hline & White+red & & & & 3 & 1 & 5 & 3 & 3 & & 15 \\
\hline & White & & & & & 5 & 6 & 9 & 3 & 8 & 31 \\
\hline & Yellow & & & & & & & 2 & 2 & & 4 \\
\hline & White+yellow & & & & & & & 1 & & & 1 \\
\hline & Yellow+red & & & & & & & 1 & & & 1 \\
\hline \multirow[t]{4}{*}{ Prints } & Orange & & & & & & & 1 & & & 1 \\
\hline & Cream & & & & & & 2 & 1 & & & 3 \\
\hline & Red (or) & & & & & 1 & 3 & 1 & 1 & & 6 \\
\hline & $\operatorname{Red}(p r)$ & & & & & 1 & & 1 & & 1 & 3 \\
\hline
\end{tabular}

were also present at the site (cf. McDonald 1995; Gunn in prep). At present the age and sex of the other stencillors can only be attributed to a group that may include adult women, adult men and/or adolescents. No large stencilled hands (knuckle $>95$ $\mathrm{mm}$ ), which are exclusively indicative of adult males, occur at the site (Gunn in prep). None of the printed hands are of infants or large adult males. The lack of very large hands contrasts with the reported size of Mulka in the story cited above, although the myth may refer to the height of some of the stencils above the floor $(>2 \mathrm{~m})$ and hence to Mulka's stature rather than the presence of his "large" hands.

There is no preference for particular ages to use particular colours (Table 6). Purple-red is the most commonly used colour amongst the hand stencils and has the widest spread of knuckle sizes. The range of hand sizes represented in the other colours covaries with the number made. A similar trend appears to occur with the handprints but, with the smaller numbers, this pattern is not as clear.

Sixteen freeform motifs could be measured. These ranged in overall size from $130 \mathrm{~mm}$ to $1270 \mathrm{~mm}$ (Table 7). There is no distinction in size between the painted and drawn motifs. Freeforms are mostly in red, with two in yellow. None are made in white or cream. The largest motif is a "simple design" prominently placed just inside the main entrance. It is $1270 \mathrm{~mm}$ long and $360 \mathrm{~mm}$ wide.

\section{Composition}

Compositions are defined as a group of apparently contemporary motifs with one or more common traits whose visual impact is greater than that of the individual motifs of which they are composed (Clegg 1978; Gunn 1997: 55). In rock art, their recognition is necessarily subjective (etic) unless an informed (emic) explanation can be given by knowledgeable informants. Aggregates of motifs can also be seen as a form of composition.

There are no distinct compositions at Mulka's Cave, although there is a tendency for hand stencils to occur in rows and to follow the irregularities in the rock surface. One group of distinctive red handstencils in the front chamber does, however, form an aggregate. These are stencilled with the second and third fingers held together, while the other fingers and thumb are splayed (Figure 7). This group appears to have been produced at the one occasion and is most probably the work of a single individual. This form of variant hands is similar to the " $3 \mathrm{mf}$ " handstencils from Arnhem Land (Chaloupka 1993: 232), where the three central digits are held together. These Arnhem Land handstencils are one element of an art phase that was produced more than 9000 years ago (Chaloupka 1984; Lewis 1988). Those at Mulka's Cave, in contrast, are likely to be much younger, given the apparent faster rate of the granite exfoliation. Although isolated examples of this

Table 7 Technique and colour by motif size ( $\mathrm{mm}$ ) (freeform motifs)

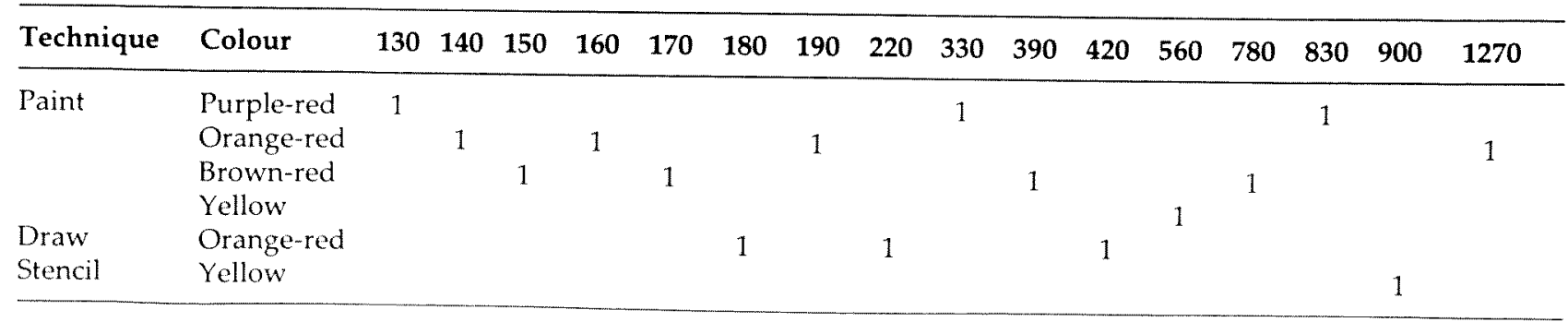


variant form will doubtless be found in the very varied stencil art of the Carnarvon Range in central Queensland (Walsh 1979), no other suites of this type are known from elsewhere in Australia.

Another variant hand in Mulka's Cave is a white handstencil in which the thumb and index finger are splayed and the other three fingers held together. This stencil is amongst a group of other white handstencils with standard splayed fingers and is likely to be the idiosyncratic work of a particular individual.

A second loose cluster of ten motifs, this time of handprints, occurs on the cusp of the ceiling between the front and main chambers (Figure 8). In nine of these, the fingers are held together and the thumb splayed. The resultant image is suggestive of a trail of macropod tracks. These motifs appear to have been made quite recently and contemporaneously, and are also most probably the work of a single individual.

Three examples of horizontally placed handstencils are noteworthy as they occur within clusters of otherwise vertically orientated hands at widely spaced locales within both chambers.

The yellow stencil placed centrally within the prominent purple nested " $\mathrm{C}$ " shapes is the younger of the two. Its placement was clearly deliberate, although whether the association was culturally meaningful is unknown.

The two most distinctive motifs within the shelter are the painted " $\mathrm{C}$ " shape just mentioned and an adjacent rambling design in orange-red. They are two of the largest motifs within the cave $(830 \mathrm{~mm}$ and $1270 \mathrm{~mm}$ respectively). Their large size and prominent location immediately inside the front chamber suggests they had considerable significance (cf. Gunn 2003c). The "C" shaped design overlies the rambling design and hence its placement was clearly calculated, to either add to the significance of the earlier motif or, alternatively, to over-ride it. The rambling design is visually comparable to other large maze designs at several shelters elsewhere in the region (Webb and Gunn 2004). They appear to form a distinct stylistic set whose nature has yet to be explored.

\section{Condition}

The condition of pigment art is assessed on the basis of the amount of pigment adhering to the

Table 8 Motif condition by technique.

\begin{tabular}{lccccc}
\hline Technique & good & fair & poor & very $p$ & $(n)$ \\
\hline$\%)$ & & & & & \\
Spray & 4 & 16 & 25 & 55 & 389 \\
Print & $\mathbf{1 1}$ & 8 & 41 & $\mathbf{4 1}$ & 37 \\
Nos & & 4 & 8 & 5 & 23 \\
Paint & 7 & 2 & 1 & & 3 \\
Draw & & & & & \\
\hline
\end{tabular}

Table 9 Motif condition by colour.

\begin{tabular}{lccccc}
\hline Colour & good & fair & poor & very $\mathrm{p}$ & $(\boldsymbol{n})$ \\
\hline \%) & & & & & \\
White & 7 & 17 & 38 & 38 & 111 \\
Red-orange & 2 & $\mathbf{1 4}$ & $\mathbf{3 5}$ & 49 & 43 \\
Red-purple & $\mathbf{4}$ & $\mathbf{1 4}$ & 20 & $\mathbf{6 2}$ & 225 \\
White+red & & 34 & $\mathbf{3 4}$ & $\mathbf{3 1}$ & 32 \\
Nos & & & & & \\
Cream & 3 & 1 & 1 & 2 & 7 \\
Red-brown & 4 & & 2 & 2 & 8 \\
Orange & 1 & & 1 & 2 & 4 \\
Yellow+red & 1 & & 1 & & 2 \\
White+yellow & & & 1 & & 1 \\
Yellow & & 4 & 2 & 13 & 19 \\
\hline
\end{tabular}

rockface. Motifs with a dense coating of pigment are said to be in excellent condition, while those with the merest of traces are allocated a very poor condition. The motifs in Mulka's Cave ranged from good to very poor. No motifs were in excellent condition, although prints and paintings tend to be better preserved than the sprayed motifs (Table 8 ). This suggests that printing and painting were more favoured over the recent period of the shelter's use.

The data for condition by colour is limited for most colours due to low numbers (Table 9). It appears that cream, brown-red, and white pigments, being among the best preserved colours, represent the most recent colours used at the site. In contrast, purple-red and orange-red have the highest proportion of very poor motifs, suggesting that they were more commonly used in the earlier period of the shelter's use.

\section{Superimposition}

Superimposition (the overlying of one motif by another) provides a sequence that can be a guide to chronology, if not age. Underlying motifs must be older than overlying ones. Eighty-seven examples of superimposition were interpreted. Many other examples of overlapping motifs also occur but their sequences could not be reliably elucidated. Not all of the aspects of the sequence (colour, technique and motif type) were clear and consequently the tallies in Tables 9-11 are not the same.

It appears that purple-red was more frequently used during the earlier period of art production, with white, cream and orange used during the latest period (Table 10). Given that white preserves very poorly (Clark 1978), it is again stressed that white may have been used during the earlier period but that the motifs have since deteriorated beyond recognition. The same may be said for cream pigments, which tend to have a white base. The lack of purple-red in the recent layers, however, does seem to be evidence of a real change in pigment preference. 
Table 10 Colour superimpositioning

\begin{tabular}{|c|c|c|c|c|c|c|c|c|c|c|}
\hline $\begin{array}{l}\text { OVERLAYER } \\
\text { UNDERLAYER }\end{array}$ & White & $\begin{array}{l}\text { Red- } \\
\text { purple }\end{array}$ & $\begin{array}{l}\text { White } \\
\text { +red }\end{array}$ & Cream & $\begin{array}{l}\text { Red- } \\
\text { orange }\end{array}$ & Orange & Yellow & $\begin{array}{c}\text { Red- } \\
\text { brown }\end{array}$ & $\begin{array}{l}\text { Yellow } \\
\text { +red }\end{array}$ & Total \\
\hline Purple-red & 18 & 15 & 8 & 4 & 6 & 2 & 1 & 1 & & 55 \\
\hline White & 9 & 2 & 1 & 1 & & 1 & & & 1 & 15 \\
\hline Yellow & 4 & 1 & & 2 & & & & & & 7 \\
\hline Orange-red & & 4 & 1 & 1 & 1 & & 2 & & & 9 \\
\hline White+red & & & & & & & & & 1 & 1 \\
\hline Total & 31 & 22 & 10 & 8 & 7 & 3 & 3 & 1 & 2 & 87 \\
\hline
\end{tabular}

Table 11 Technique superimpositioning.

\begin{tabular}{lcccc}
\hline & \multicolumn{4}{c}{ OVERLAYER } \\
UNDERLAYER & Spray & Print & Paint & Draw \\
\hline Spray & 43 & 17 & 9 & 2 \\
Paint & & & 4 & 2 \\
Print & 1 & & & \\
\hline
\end{tabular}

Table 12 Hand superimpositioning.

\begin{tabular}{lcccc}
\hline UNDERLAYER & Left & $\begin{array}{c}\text { OVERLAYER } \\
\text { Right }\end{array}$ & $\begin{array}{l}\text { Unknown } \\
\text { Lnagment }\end{array}$ \\
\hline Left & 12 & 3 & 6 & \\
Right & 7 & 4 & 3 & \\
Unknown & 8 & 3 & 4 & 2 \\
Fragment & 1 & 1 & 1 & \\
Variant & 2 & & & \\
Spray area & 4 & &
\end{tabular}

\section{Age and chronology}

Condition by technique and colour suggest that cream, brown-red and white prints, paintings and sprayed motifs are more recent than purple-red sprayed motifs. However, as there is considerable overlap of the two groups, no clear division can be made on the basis of preservation alone. Further, red pigments (ochres) usually preserve better in rock art than white (kaolin or other pipeclays) (e.g., Clarke 1978). Also, it is possible that white pigment was used during the earlier period of shelter use but that these motifs have completely deteriorated, leaving no archaeological evidence of their earlier presence. The picture is further complicated by the unusual situation of the apparent placement of white stencils over a prepared or incidental red ground. On those few of the motifs that retain white pigment, the white appears to be relatively recent. This suggests that some particularly rapid deterioration process is occurring to these motifs, masking their recent production. Consequently, condition here is not a reliable indicator of motif age.

Similarly, superimpositioning of techniques suggests that, of the surviving techniques, spraying was the first used at the site, and that printing, painting and drawing were introduced into the repertoire at a later time (Table 11). Also, there was no change in the preference for hands over time, with right and left hands occurring in similar proportions in both the earlier and the more recent periods of artwork (Table 12). Taken together, motif condition and superimposition indicate a bipartite art sequence in which purple-red sprayed motifs predate sprays, prints and paintings in cream, brown-red, and white.

The presence of many superimposed motifs indicates that the site has been used for a considerable period of time, most likely a far greater period than is represented by the 500 year old carbon date (Bowdler et al. 1989). In common with many other rock art sites throughout Australia, it is likely that the artwork here was produced over the past two or three thousand years (Mulvaney and Kamminga 1999, David 2002). Handstencils are amongst the earliest rock art throughout Australia (Morwood 2002) and excavations around the rim of the Wheatbelt have demonstrated Pleistocene occupation of southwestern Australia (Bordes et al. 1983; C. Dortch 1979; J. Dortch 1996). However, apart from walganha, the few decorated shelters that have been excavated are in broad agreement with the younger age. For example, Frieze Cave, an art site some 200 $\mathrm{km}$ to the west of Mulka's Cave and $100 \mathrm{~km}$ inland from Perth, produced an occupation phase dating from $<3000 \mathrm{BP}$ to the ethnographic present (Hallam 1972). In the Murchison District, $600 \mathrm{~km}$ to the north of Mulka's Cave, most decorated shelters have occupation similarly limited to the last 4500 years (Webb in prep.).

\section{The floor deposits and surface scatter}

A team from the University of Western Australia excavated a test pit in the floor of the lower shelter in 1989 (Bowler et al. 1989). The pit, one metre square and excavated to bedrock at a depth of 1.10 $\mathrm{m}$, was placed about half a metre inside the dripline (Figure 4). A limited stone artefact assemblage was recovered, along with faunal remains representative of several genera native to the region (principally small mammals such as bettong and possums, but no large kangaroos). The artefacts were dominated by rock types of quartz, with small numbers of 
dolerite, sedimentary rock, and granite. Red and yellow ochres were also present. Apart from the few dolerite, sedimentary artefacts and the ochres, which would have to have been imported into the site from some distance, the granite and predominant quartz could be obtained locally from outcrops on the hill. The lowest artefact was recovered at $0.7 \mathrm{~m}$, from a pit-like feature interpreted as a drainage channel. Charcoal recovered from a depth of $0.65 \mathrm{~m}$ was dated to $420+50 \mathrm{BP}$.

The excavators concluded that the site had been only briefly or periodically occupied and suggested that the late occupation of the site (c.500 BP) was consistent with the "intensification phenomena" associated with the late Holocene use of marginal resource zones. However, given the disturbed and water-washed nature of the excavated deposits, their conclusions are unlikely to be representative of the site's overall occupation. Consequently, their interpretation of brief or periodic occupation is not seen as definitive. Likewise their c.500 BP date, coming from a refilled drainage line, cannot be taken to represent the initial period of shelter use. Clearly, further excavation at the site would be required if the period of use of the shelter and its outside deposits are to be more precisely dated.

Run-off has eroded a gutter out from the front of the main entrance to the shelter, $100 \mathrm{~mm}$ deep, exposing numerous stone artefacts. Artefacts are lightly scattered over an area $100 \mathrm{~m} \mathrm{~N}-\mathrm{S}$ and $20 \mathrm{~m}$ E-W, following around the base of the rocky outcrop. This distribution suggests that while the cave was a focal point for people coming to the site, most of the occupation occurred on the flat open ground outside the cave; a situation commonly observed in arid areas but also noted in southern woodland areas (cf. Gunn 1997, 2003b).

In a sample of 132 artefacts from the gully analysed during the present project, quartz
Table 13 Artefact stone types

\begin{tabular}{lrr}
\hline Stone type & No & $\%$ \\
\hline Milky qz & 78 & 60 \\
Clear (non-crystal) $q z$ & 47 & 36 \\
Silcrete & 2 & 1 \\
Banded ironstone & 2 & 1 \\
Ochre (red) & 2 & 1 \\
Other siliceous & 1 & $>1$ \\
Total & 132 & 100 \\
\hline
\end{tabular}

accounted for $96 \%$ of the artefacts, with silcrete, banded ironstone, an unidentified siliceous stone and ochre making up the remainder (Table 13). Quartz is readily available from a major outcrop near Captain Roe Rocks, $25 \mathrm{~km}$ south-west of The Humps, and in smaller seams on The Humps itself and other granite domes in the region. Banded ironstone outcrops occur in the rises of the Southern Mineral Field north of Lake Cronin, $70 \mathrm{~km}$ to the east (Geological Survey of Western Australia 2003). A source for the silcrete is unknown. One of the red ochre nodules is an orange-red and has a flat facet with striation marks, consistent with being ground for use. The other piece is brown-red and unmarked. Both colours are represented in the artwork.

The artefacts were mostly (95\%) small: $<25 \mathrm{~mm}$. They consisted of debitage fragments (without platform or bulb; 110 or $83 \%$ ), flakes (with platform and/or bulb; 16 or $12 \%$ ), backed flakes ( 3 or $2 \%$ ), one retouched flake (unifacial and uni-marginal scraper) and two nodules of red ochre (Table 14). Four geometric microliths were located near the main entrance, away from the gutter (Figure 14). These tool types are characteristic of the Australian Small Tool Tradition and are therefore likely to be less than 6000 years old (Mulvaney and Kamminga 1999).

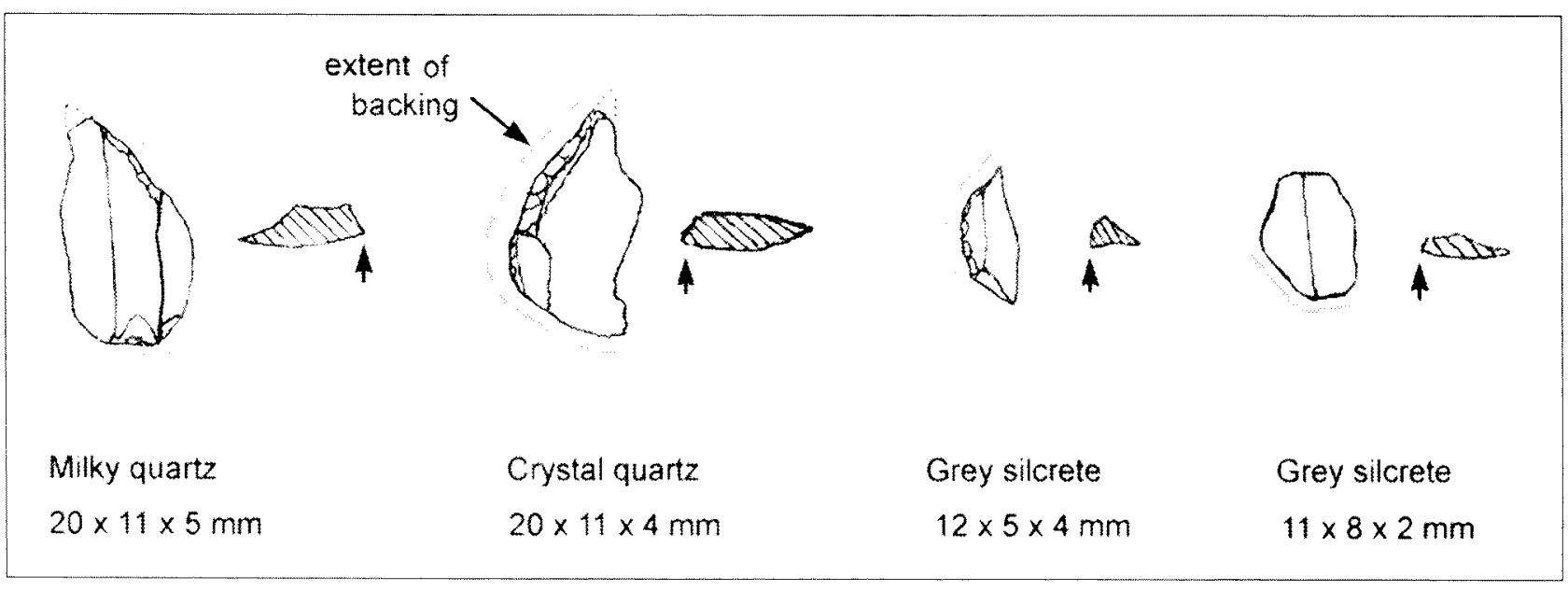

Figure 14 Field drawings of select geometric microliths. 
Table 14 Artefact summaries.

\begin{tabular}{|c|c|c|c|c|c|c|c|c|c|c|}
\hline Artefact type & $\begin{array}{l}\text { Size }(\mathrm{mm}) \\
\text { Stone type }\end{array}$ & $6-10$ & 11-15 & $16-20$ & $21-25$ & $26-30$ & $31-35$ & $81-85$ & broken & Total \\
\hline \multirow[t]{3}{*}{ Chips } & Milky quartz & 9 & 20 & 29 & 15 & 1 & & & & 74 \\
\hline & Clear quartz & 11 & 19 & 5 & & & & & & 35 \\
\hline & Silcrete & 1 & & & & & & & & 1 \\
\hline \multirow[t]{4}{*}{ Flakes } & Milky quartz & & 2 & & & & & & 2 & 4 \\
\hline & Clear quartz & 1 & 4 & 4 & & & & & 1 & 10 \\
\hline & Banded iron & & & & & & 1 & & & 1 \\
\hline & Other & & & 1 & & & & & & 1 \\
\hline Backed flake & Clear quartz & & 2 & & & & & & & 2 \\
\hline $\begin{array}{l}\text { (geometric } \\
\text { microliths) }\end{array}$ & Silcrete & 1 & & & & & & & & 1 \\
\hline Retouched flake & Banded iron & & & & & & & 1 & & 1 \\
\hline Ochre nodule & & & & & 2 & & & & & 2 \\
\hline Total & & 23 & 47 & 39 & 17 & 1 & 1 & 1 & 3 & 132 \\
\hline
\end{tabular}

\section{OTHER ARCHAEOLOGICAL SITES}

\section{Lizard traps}

Although little documented in the literature (see Webb and Gunn 2004), "lizard traps" are a widely distributed and well-known Aboriginal site-type in south-western Western Australia. Generally they consist of a thin granite slab, around $100 \mathrm{~cm}$ square and $10 \mathrm{~cm}$ thick (Webb and Gunn 2004), propped on one end to a height of $10 \mathrm{~cm}$, using one or more smaller stones (usually around $10 \mathrm{~cm}$ diameter). The trap at The Humps is quite large ( 240 by 120 by
$17 \mathrm{~cm})$. It is raised $13 \mathrm{~cm}$ off the pavement at its upslope end by two small rocks (Figure 15). How, indeed if, they were used is unknown. Given the adeptness of traditional desert Aborigines in catching lizards (cf. Gould 1969b, Tonkinson 1978), the raised slab was probably an artificial crevice beneath which the lizards could retreat to when disturbed; only then to be caught with nowhere else to run. There would seem to be no point in dropping the rock onto and crushing any hiding animals, as has been suggested in colloquial discussions.

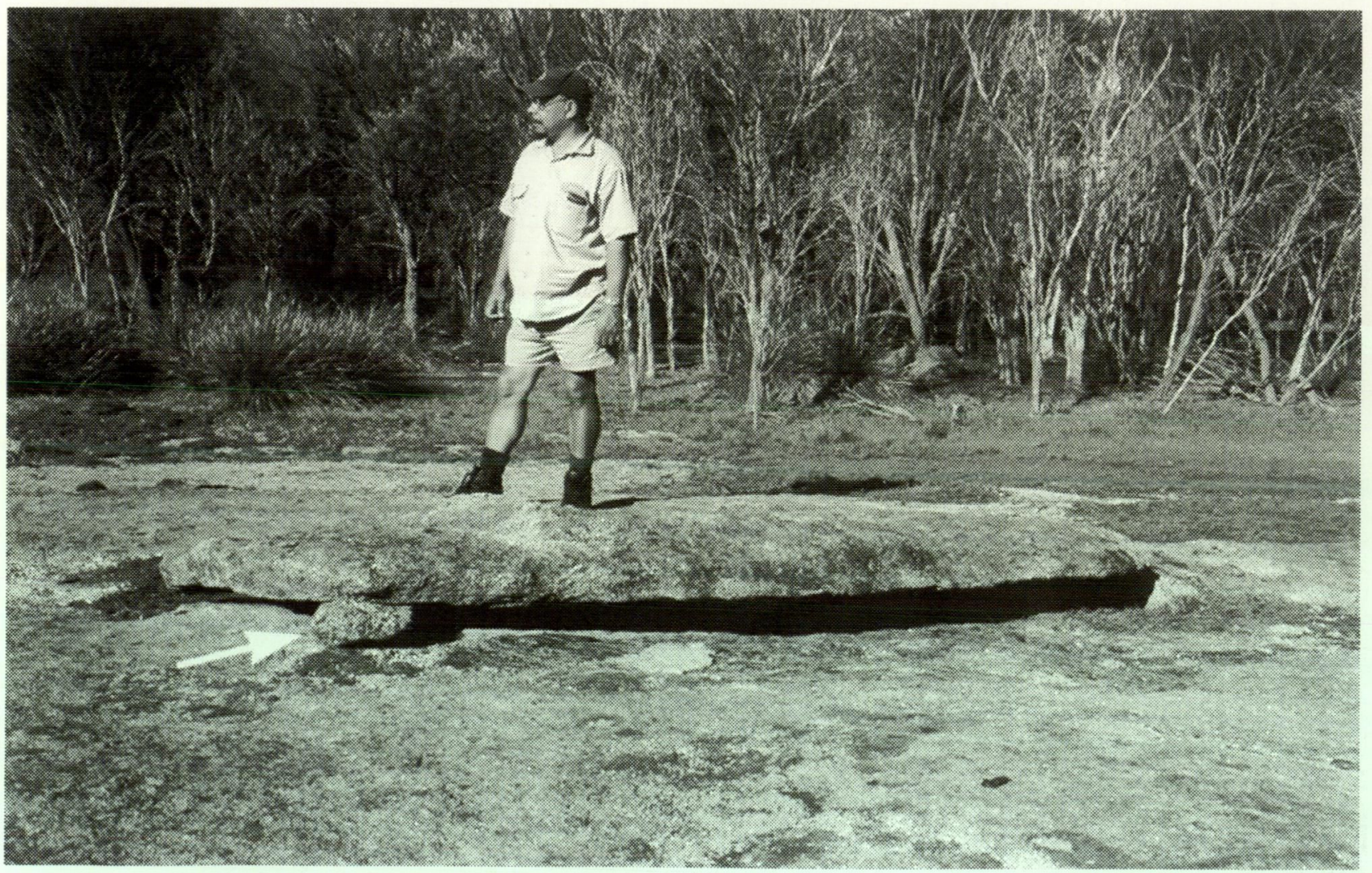

Figure 15 The Humps lizard trap site with support rock arrowed. 
Water reserves

Gnammas, rockholes and pans are different types of depressions in impermeable bedrock that can catch and hold water after rain. Although gnammas and pans are formed by the same geological process (Twidale and Corbin 1963), archaeologically a distinction is made between pit gnammas (gnammas) and pan gnammas (pans) as the former have a good depth relative to their width and hence hold water for a good deal longer than pans, which are broad and relatively shallow (up to $20 \mathrm{~cm}$ ) and are readily evaporated. Gnammas are essentially rain-fed. In contrast to gnammas, rockholes form along creek lines, usually as plunge pools, and are fed by the creek-flow.

Throughout the Murchison/Wheatbelt area, gnammas were a well-known, well-utilised and highly valued water source for Aborigines and the early settlers (Bowdler et al. 1989; Bindon 1997; Webb and Gunn 2004). They provided a reliable reserve that could be targeted by people familiar with the country in which they occur (e.g., Gould 1969a, Myers 1991). Rockholes tend to develop at the base of escarpments, whereas pans develop on top of suitable rock exposures such as granite domes and duricrust surfaces on top of escarpments. Many gnammas, in contrast, occur as nondescript features in a superficially nondescript landscape and would be impossible to intentionally locate without detailed knowledge of the country (e.g., Gunn and Webb 2003). Many also had granite slab "lids" to prevent animals draining the supply and to reduce evaporation (e.g., Webb and Gunn 2004). Traditionally, rockholes and gnammas would have had Aboriginal names and some associated mythology. Pans, on the other hand, were not regarded as highly because of the more limited life of their reserves due to evaporation.

Five gnammas have been located on and around The Humps (Figure 3). Four occur on the granite pediment to the north of the Mulka's Cave. Two are quite large (e.g., Figure 16); whereas the two adjacent to the lizard trap are very small (Table 15). The fifth occurs on the northern mid-slope of the hill.

A sizeable rockhole has formed within a shallow drainage line that flows off the hill to the north of Mulka's Cave. The ephemeral stream that feeds this rockhole is a prominent feature of the hill. It supports a number of well-vegetated soil patches on an otherwise steep and barren rock slope. The stream flows readily after rain, and continues to trickle for some days after rain (personal observations). The rockhole measures 8.5 by 2.0 by $0.8 \mathrm{~m}$. It has a " $\mathrm{V}$ " profile and contains some 650 litres of water when full. As the stream leaves the hill it winds into granite sands that quickly become boggy. It is likely that small sub-surface soaks

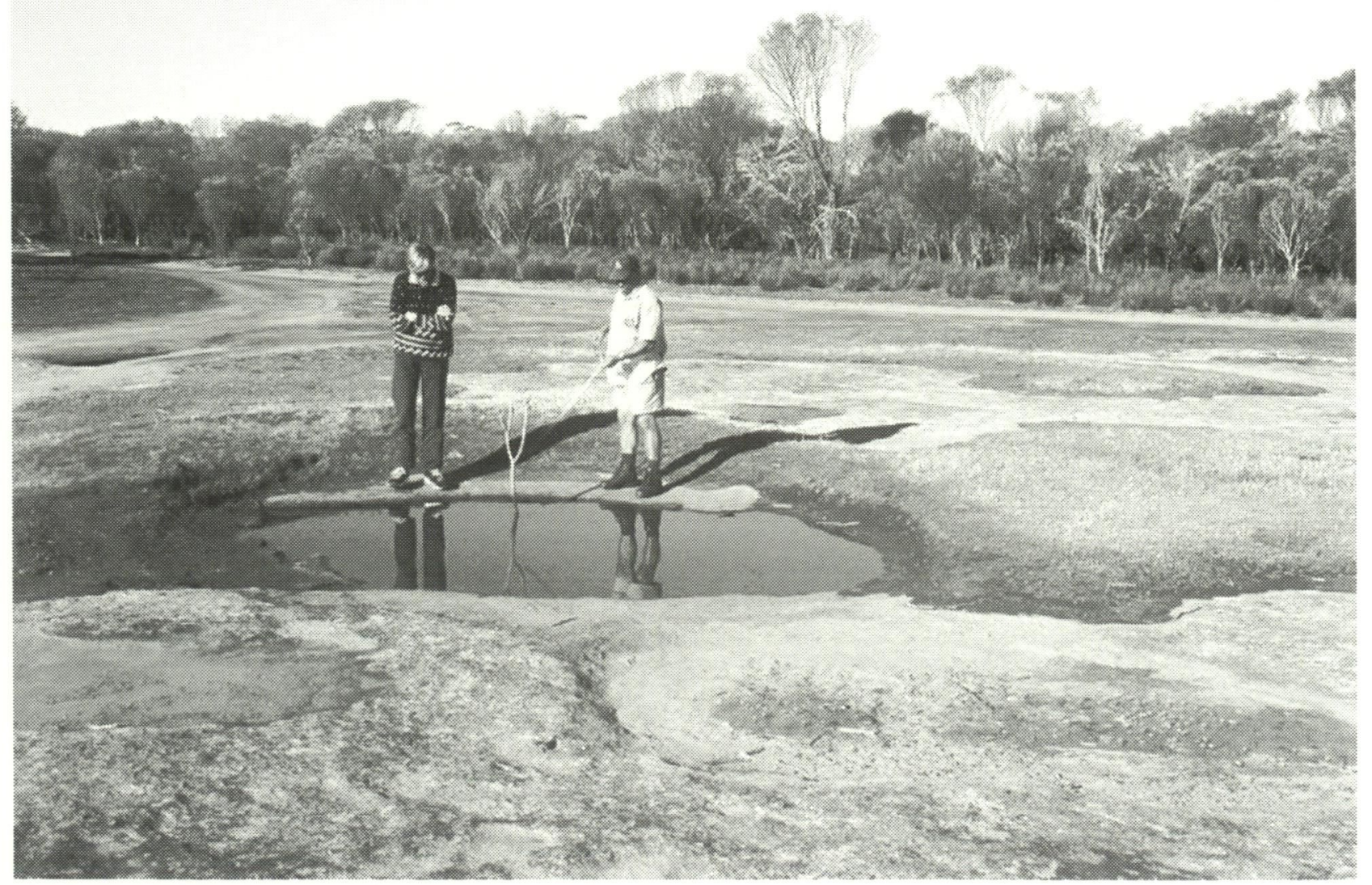

Figure 16 The largest gnamma at The Humps. 
Table 15 Gnamma dimensions and approximate volumes

\begin{tabular}{lcccc}
\hline Site & $\begin{array}{c}\text { Length } \\
(\mathbf{m})\end{array}$ & $\begin{array}{c}\text { Width } \\
(\mathbf{m})\end{array}$ & $\begin{array}{c}\text { Depth } \\
(\mathbf{m})\end{array}$ & $\begin{array}{c}\text { Capacity } \\
(\mathbf{l})\end{array}$ \\
\hline Humps 1 & 1.40 & 0.85 & 0.65 & 77 \\
Humps 2 & 4.00 & 2.50 & 0.60 & 300 \\
Humps 3 & 0.45 & 0.20 & 0.30 & 3 \\
Humps 4 & 0.20 & 0.15 & 0.20 & 1 \\
Humps 5 upper pan & 0.85 & 0.60 & 0.20 & 13 \\
\hline
\end{tabular}

would be available along the stream's path for some time after the rockhole had dried.

The pans on top of the hill are numerous and large (around 4.0 by 2.0 by $0.1 \mathrm{~m}$ ) and together, after rain, would probably hold around 1000 litres of water. With another 1200 litres held over in the gnammas and rockhole, and the possibility of subsurface soaks along the stream bed, a good minimum supply of around 2000-3000 litres could be ensured: more than enough for an extended family group's transitory stopover or a larger gathering for brief periods. The presence of these reserves may well explain why Mulka's Cave was chosen for decoration.

\section{AN INTERPRETATION OF MULKA'S CAVE}

In common with other sites in the Wheatbelt (Davidson 1952; Wolfe-Okongwu 1978; Webb and Gunn 2004; Dept. Indigenous Affairs, Perth, records), the art of Mulka's Cave is dominated by handstencils, but it also includes a small number of large and visually impressive linear paintings. The site also houses a small number of less impressive handprints, small paintings and drawings. Mulka's Cave, with a total of 452 motifs, has a far higher quantity of rock art than most other Wheatbelt rock art sites, which tend to have fewer than 30 motifs. The artwork also utilises a wider range of colours than other regional sites.

As McDonald (1995) inferred for rock art sites in the Sydney Basin, the presence of infant handstencils and others that most likely are those of women and adolescence suggests that at some times family groups camped by and used the cave. The unsuitability of the cave's floor for sleeping suggest that the cave was used as a wet weather retreat and that most camping occurred on the level ground in front of the cave. This is supported by the pattern of surface artefact distribution.

On the other hand, the painting of large geometric designs are almost certainly the work of senior males and most likely refer to the Dreaming tracks of totemic ancestors, as they do in the Western Desert and Central Australia (Spencer and Gillen 1899; Gould 1969b; Bardon 1979; Myers 1991). These paintings and the associated Mulka story suggest that, at times, the cave was associated with local nearby rituals, at which times it would have been off-limits to women and children. A similar dual-use has been proposed for the densely decorated shelter at walganha (Walga Rock), which was known to have been used for ritual in the recent past but was apparently open to women and children at non-ceremonial times (Gunn et al. 1997).

Overall then, it is suggested that Mulka's Cave was used by the full age-range of the population, although whether at the same time or at different times for different purposes, is yet to be determined. This view does not support the suggestion that the cave was used as a store-house for ceremonial objects (Serventy 1952), as such store-houses were, and in many areas still are, invariably accessed only by senior males and are always off-limits to women and children (e.g., Gould 1969b, Mountford 1976).

The large area of the campsite in front of the shelter along with the higher number of stone artefacts relative to other art sites in the region suggests that occupation here was indeed recurrent; but whether through short-term, large gatherings or prolonged occupation by small family groups is likewise unknown. The artefacts were made from a limited array of raw materials, all available locally, suggesting that Mulka's Cave was not a focus for large inter-regional gatherings when materials from well outside the region would be brought in by the visitors.

Most water sources and granite outcrops within the region, particularly those with rock art or stone arrangements, probably had associated myths similar to the Mulka story recorded for this site. This was certainly the case elsewhere in Australia where such information has been collected (e.g., Hallam 1972; Berndt and Berndt 1977: 243-256; Strehlow 1978; Myers 1991). Hence, while it is tempting to give some special credence to Mulka's Cave because of the survival of the Mulka myth, this should not be seen as particularly unusual. On the other hand, some myths were more significant than others, possibly due to the strengths of particular clans or individuals (see Spencer and Gillen 1899). Whether the Mulka story was of regional significance or of only local importance is 
unknown. The high quantity of artwork, the wide range of colours used, the size of the campsite and the extensive area encompassed by the myth, suggest that Mulka's Cave had at least a regional significance. In contrast to this, the restricted range of motif types used suggests that the site was not a place of inter-tribal gatherings or "aggregation site" as defined by Conkey (1980) and Galt-Smith (1997). At most, the Mulka's Cave site complex would seem likely to have been a focus for local group ceremonies, such as initiation or maintenance rituals. From what we know of such rituals, they were invariably focused on open areas away from general campsites and that rock art use was generally a tangential, albeit important, component of the main ceremony. It is therefore unlikely that Mulka's Cave itself was the principal focus for these ceremonies. If ceremonies did take place at The Humps, they would have been held nearby, either on the dome or out on the adjacent plains, with visits to the cave just one aspect of the ceremony. A likely location for the performance of the main ceremony has not been located.

\section{CONCLUSION}

In keeping with the regional profile, the rock art preserved within Mulka's Cave is dominated by handstencils but with a small number of geometric designs. Typically however, one or two of the latter are the largest and most visually impressive motifs within the site. The suite at Mulka's Cave is the densest concentration of rock art yet recorded within south-western Western Australia and consequently must be seen to be one of the most significant archaeological sites within the region.

Similarly, the artefact scatter in front of the shelter is far denser than those noted at most other rock art complexes in south-western Australia (Webb and Gunn 2004), suggesting that the site was important as a recurrent focus of occupation. The archaeological potential of the deposits here have been tested but have yet to be explored to their full depth. The importance of this potential must be acknowledged in the future management of the site.

The interpretation of the evidence to date, although based on analogies from other areas, suggests that the site was used both for ritual purposes related to broader ceremonies held nearby and, probably at different times, for general occupation.

Today, Mulka's Cave is of great significance to the local Noongar community and also, but for different reasons, to non-Indigenous residents of the region and the local tourist industry. It is one of the most visited rock art sites in Western Australia and hence has a broad potential for positive educational uses.

The main focus of this study was to document the site and illustrate the importance of its' rock art. It is hoped that this will ensure that Mulka's Cave, and The Humps Reserve in which it lies, continues to be managed and interpreted, in a culturally sensitive manner, to the highest standards are available.

\section{ACKNOWLEDGEMENTS}

The recording project was funded jointly by the Department of Indigenous Affairs (Southern Region) and the Hyden-Karlgarin Landcare Council, and supervised by Robert Reynolds (DIA Midlands) and Anthony Galante (DIA Southern Region). It would not have occurred without the support of the native title claimants. Robert Reynolds and Brian Blurton (DIA), Monica JimenezLozano, Alana Rossi and Jodee Smith (Honours graduates from the University of Western Australia) also assisted in the field. Jane Mouritz (Hyden) organised the essential generator and floodlights. I also thank Esmee Webb (Edith Cowan University) for her patience, as the project was undertaken midway through fieldwork with her on another study. I also profited from discussions with Rowle Twidale regarding geological terminology. Sylvia Hallam and Charlie Dortch reviewed the paper and made me rethink several of my propositions, while Esmee Webb, Leigh Douglas and Sarah Turnbull also offered suggestions for improving my English. The author however, takes full responsibility for the final presentation and the conclusions presented.

\section{REFERENCES}

Bardon, G. (1979). Aboriginal Art of the Western Desert. Rigby, Adelaide.

Berndt, R. M. (1980). Aborigines of the south-west. In R. M. Berndt and C. M. Berndt (eds) Aborigines of the West, pp. 81-89. University of Western Australia Press, Perth.

Berndt, R. M. and Berndt, C. H. (1977). The World of the First Australians. Ure Smith, Sydney.

Bindon, P. (1997). Aboriginal people and granite domes. Journal of the Royal Society of Western Australia 80: 173179.

Bordes, F., Dortch, C.E., Thibault, C., Raynal, J-P. and Bindon, P. (1983). Walga Rock and Billibilong Spring: two archaeological sequences from the Murchison Basin, Western Australia. Australian Archaeology 17: $1-26$.

Bowdler, S., Harris, J., Murphy, A., Nayton, G. and Pocock, C. (1989). Test excavations at Mulka's (Bate's) Cave near Hyden. Unpublished report to the Department of Aboriginal Sites, Western Australian Museum, Perth.

Chaloupka, G. (1984). From Paleo Art to Casual Paintings. Northern Territory Museum of Arts and Sciences Monograph Series 1, Darwin.

Chaloupka, G. (1993). Journey in Time: the World's Longest Continuing Art Tradition. Reed, Chatswood. 
Clarke, J. (1976). Graffiti removal, Bate's Cave, Hyden, Western Australia. Unpublished report to the Department of Aboriginal Sites, Western Australian Museum, Perth.

Clarke, J. (1978). Deterioration analysis of rock art sites. In C. Pearson (ed.) Conservation in rock art, pp. 54-63. Institute for the Conservation of Cultural Material, Perth.

Clegg, J. (1978). Mathesis words, mathesis pictures. Unpublished MA thesis, Dept. Anthropology, University of Sydney.

Clegg, J. (1987). Human picturing behaviour and the study of prehistoric pictures. Rock Art Research 4: 2935.

Conkey, M. (1980). The identification of prehistoric hunter-gatherer aggregation sites: the case of Altamira. Current Anthropology 21: 609-630.

David, B. (2002). Landscapes, Rock Art and the Dreaming: an Archaeology of Preunderstanding. Leicester University Press, Leicester.

Davidson, D. S. (1952). Notes on the pictographs and petroglyphs of Western Australia and a discussion of their affinities with appearances elsewhere on the continent. Proceedings of the American Philosophical Society 96: 76-117.

Day, R. B. (1951). Western Australian, 27 January 1951.

Department of Aboriginal Sites (1989). Mulka's Cave (also known as Bates Cave), Hyden, Western Australia. Brochure, Dept. Aboriginal Sites, West Perth.

Dortch, C. (1979). Devil's Lair, an example of prolonged cave use in Western Australia. World Archaeology 10: 258-279.

Dortch, J. (1996). Late Pleistocene and recent occupation of Tunnel Cave and Witchcliffe Rock Shelter, southwestern Australia. Australian Aboriginal Studies 1996/ II: $51-60$.

Flood, J. (1990). The Riches of Ancient Australia. University of Queensland Press, St. Lucia.

Gale, F. and Jacobs, J. M. (1987). Tourism and the National Estate. Australian Government Publishing Service, Canberra.

Galt-Smith, B. (1997). Motives for motifs. Unpublished BA Honours thesis, University of New England, Armidale.

Geological Survey of Western Australia (2003). Geological Atlas of Western Australia. CD-ROM version. Geological Survey of Western Australia, Department of Industry and Resources, Perth.

Gould, R. A. (1969a). Subsistence behaviour among the Western Desert Aborigines of Western Australia. Oceania 39: 253-274.

Gould, R. A. (1969b). Yiwara: Foragers of the Australian Desert, Charles Scribner's Sons, New York.

Gunn, R. G. (1981). The Aboriginal rock art of the Mt Lofty Ranges, SA. Uncommissioned report to the Dept. of the Environment, Adelaide.

Gunn, R. G. (1983). Aboriginal rock art in the Grampians. Records of the Victorian Archaeological Survey No 16. Ministry for Conservation, Melbourne.

Gunn, R. G. (1995a). Recording rock images for management purposes. In G. K. Ward and L. A. Ward (eds) Management of rock imagery, pp. 93-96.
Occasional AURA Publication No.9. Australian Rock Art Research Association, Melbourne.

Gunn, R. G. (1995b). Guidelines for recording Australian Aboriginal rock imagery. In G. K. Ward and L. A. Ward (eds) Management of rock imagery, pp. 124127. Occasional AURA Publication No.9. Australian Rock Art Research Association, Melbourne.

Gunn, R. G. (1997). Arrernte rock art, occupation and myth: the correspondence of symbolic and archaeological sites at rock art complexes in Central Australia. Rock Art Research 14: 124-136.

Gunn, R. G. (2002). Mudgegonga-2 and the rock art of north-east Victoria. Rock Art Research 19: 117-132.

Gunn, R. G. (2003a). Mulka's Cave Aboriginal rock art site: A discussion of management options. Unpublished report to the Department of Indigenous Affairs, Midlands.

Gunn, R. G. (2003b). Three more pieces to the puzzle: Aboriginal occupation of Gariwerd (Grampians), Western Victoria. The Artefact 26: 32-50

Gunn, R. G. (2003c). Arrernte rock-art: interpreting physical permanence in a changing social landscape. Australian Aboriginal Studies 2003: 52-73.

Gunn, R. G. (2004). Mulka's Cave Aboriginal rock art site: an archaeological recording. Unpublished report to the Department of Indigenous Affairs, Albany, and the Hyden- Karlgarin and District Landcare Group, Hyden.

Gunn, R. G. (in prep) Hand sizes in rock art: Interpreting the measurements of hand stencils and prints in central Australia. Rock Art Research.

Gunn, R. G. and Webb, R. E. (2003). Art and archaeology on Coodardy, Austin Downs and Noondie pastoral leases, west of Cue. Unpublished report to the Thoo Thoo Warninha Aboriginal Cooperative, Cue, and the Australian Institute of Aboriginal and Torres Strait Islander Studies, Canberra.

Gunn, R. G., Webb, E. and Marmion, D. (1997). Walganha (Walga rock): a Wajarri rock art and Dreaming site. Report to the Yamaji Language Centre, Geraldton, and the Australian Heritage Commission, Canberra.

Hallam, S. J. (1972). An archaeological study of the Perth area, Western Australia: a progress report on art and artefacts, dates and demography. Australian Institute of Aboriginal Studies Newsletter 3(5): 11-19.

Haydock, P. and Rodda, J. (1986). A survey of rock art conservation in the Murchison/Wheatbelt area of WA: a study of past treatments and new methods of measurement and site management. Unpublished report of the Department of Aboriginal Sites, Western Australian Museum, Perth.

Lewis, D. (1988). The Rock Paintings of Arnhem Land, Australia. BAR International Series 415, Oxford.

McDonald, J. (1983). The identification of species in a Panaramitee style engraving site. In M. Smith (ed.) Archaeology at Anzaas 1983, pp. 236-272. Western Australian Museum, Perth.

McDonald, J. (1995). Looking for a woman's touch: indications of gender in shelter sites in the Sydney Basin. In J. Balme and W. Beck (eds) Gendered archaeology: the second Australian Women in Archaeology Conference, pp. 92-96. ANH 
Publications, Australian National University, Canberra.

Maynard, L. (1977). Classification and terminology in Australian rock art. In P. J. Ucko (ed.) Form in indigenous art, pp. 387-402. Australian Institute of Aboriginal Studies, Canberra.

Maynard, L. (1979). The archaeology of Australian Aboriginal art. In S. Mead (ed.) Exploring the visual arts of Oceania, pp. 83-111. University Press, Hawaii.

Meeking, J. (1979). The History of Hyden. Mid-West Print, Northam.

Meggitt, M. J. (1962). Desert People. Angus and Robinson, Sydney. (1974 edition).

Morwood, M. J. (2002). Visions from the Past: the Archaeology of Australian Aboriginal Art. Allen and Unwin, Sydney.

Mountford, C. P. (1976). Nomads of the Australian Desert. Rigby, Adelaide.

Mulvaney, D. J. and Kamminga, J. (1999). Prehistory of Australia. Allen and Unwin, Sydney.

Myers, F. R. (1991). Pintubi Country, Pintubi Self. University of California Press, Berkeley.

O'Conner, S., Veth, P. and Campbell, C. (1998). Serpent's Glen rockshelter: report of the first Pleistocene-aged occupation sequence from the Western Desert. Australian Archaeology 46: 12-22.

Randolph, P. (1973). Bates Cave, Hyden. Unpublished report of the Department of Aboriginal Sites, Western Australian Museum, Perth.

Roe, J. S. (1852). Report of an expedition under the Surveyor General, Mr J. S. Roe, to the south-eastward of Perth, in Western Australia, between the months of September, 1848, and February, 1849, to the Hon. the Colonial Secretary. Journal of the Royal Geographic Society 22: 1-57.

Ross, J. (2003). Rock art, ritual and relationships: an archaeological analysis of rock art from the central Australian arid zone. Unpublished PhD thesis, University of New England, Armidale.

Serventy, V. (1952). Cave paintings near York and Hyden. Western Australian Naturalist 13(5): 121-130.

Spencer, B. and Gillen, F. J. (1899). The Native Tribes of Central Australia. Macmillan and Company, London.
Strehlow, T. G. H. (1978). Central Australian Religion: Personal Monototemism in a Polytotemic Community. Australian Association for the Study of Religions, Bedford Park.

Tonkinson, R. (1978). The Mardudjara Aborigines. Holt, Rinehart and Winston, New York.

Thorn, A. (2001). Conservation of Mt Pilot sites. Unpublished report to Aboriginal Affairs Victoria, Melbourne.

Tindale, N. B. (1974). Aboriginal Tribes of Australia: their Terrain, Environmental Controls, Distribution, Limits, and Proper Names. ANU Press, Canberra.

Twidale, C. R. (1980). Geomorphology. Nelson, Melbourne.

Twidale, C. R. and Bourne, J. A. (1975). The subsurface initiation of some minor granite landforms. Journal of the Geological Society of Australia, 22: 477-484.

Twidale, C. R. and Bourne, J. A. (2003). Proposed survey of the Humps. Unpublished MS on file with the Tourism Officer, Shire of Kondinin.

Twidale, C. R. and Corbin, E. M. (1963). Gnammas. Revue de Geomorphologie Dynamique 14: 1-20.

Walsh, G. L. (1979). Mutilated hand or signal stencils? Australian Archaeology 9:33-41.

Webb, R. E. (in prep.). Results of test excavating three decorated rock shelters on Wutha country, east of Cue, Western Australia. Report to the Australian Institute of Aboriginal and Torres Strait Islander Studies, Canberra, the Wutha native title claimants and Thoo Thoo Warninha Aboriginal Corporation, Cue.

Webb, R. E. and Gunn, R. G. (2004). Re-recording culturally significant sites in south-western Australia as a guide to Noongar usage of the region in the past. Rock Art Research 21: 93-97.

Wolfe-Okongwu, W. (1978). Aboriginal art of south-west of Western Australia. Unpublished BA (Honours) thesis, Department of Anthropology, University of Western Australia, Perth.

Manuscript received 6 October 2004; accepted 26 July 2005 